\title{
Rare Books
}

\section{Thd Therr Prices}









$$
\text { and their Prices }
$$ \\ and their Prices \\ (1) \\ (1)}

Rare Books
and their Prices

Rare Books
and their Prices

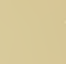

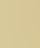

- 



\section{Rare Books And Their Prices}

With Chapters on

Pictures Pottery Porcelain

and

Postage Stamps

W. "liam $^{\mathrm{BY}}$

NEW YORK

LONGMANS, GREEN, AND CO.

1896 
<smiles>C1CCCCCC1</smiles> 


\section{Preface}

The first portion of the chapter on Books and the second Chapter on Pictures bave appeared in the Nineteenth Century; the second portion of the chapter on Books, and also those chapters dealing with Porcetain and Postage Stamps, were first published in the Fortnightly Review, to the respective Editors of which important periodicals I desire to express my thanks for their permission to reprint these papers. Each article bas been most carefully revised, and very considerably amplified.

$W . R$. 



\section{Contents}

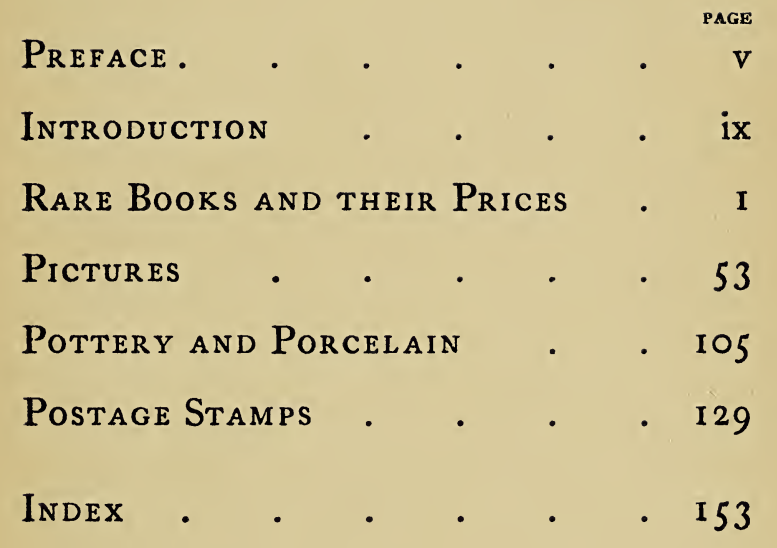





\section{Introductory}

According to La Bruyère, Curiosity, by which is meant the passion for collecting objects of art or interest, is not a taste for that which is good or that which is beautiful, but for that which is rare, or that which nobody else has. It is not (the same philosopher goes on to say) an attachment for that which is perfect, but for that which is couru, and that which is à la mode. It is not an amusement, but a passion-often so violent, indeed, that it takes precedence of both love and ambition. There is much that is true in La Bruyère's generalisations, but there is also much of the suggestio falsi. Every man and boy collects something, and therefore possesses the collecting instinct more or less deeply grained in their natures. As with every other phase of human life, the collecting instinct is largely a matter of environment and associations, tempered undoubtedly by individualism. There is the same hunger, for example, with the picture-collector as with the boy ix 


\section{Introductory}

who collects postage stamps or tram-tickets, the chief difference indeed being a mere question of taste and of money.

The enthusiasm which is inevitably born of the collecting spirit too often develops into a mania for the infinitely little, the excrescences, in fact, of the particular hobby. "C'est elle," exclaims the Bibliomaniac in "Les Loisirs" -

"C'est elle ... Dieux, que je suis aise!

Qui .... c'est .... la bonne édition;

Voilà bien, pages neuf et seize,

Les deux fautes d'impression

Qui ne sont pas dans la mauvaise."

It is not, however, with those whom Voltaire, in "Le Temple du Goût," has classified as-

"L'amas curieux et bizarre

De vieux manuscrits vermoulus,

Et la suite inutile et rare

D'écrivains qu'on n'a jamais lus,"

that we purpose dealing either in this Introduction or in the book itself. It is a hopeless task, moreover, to attempt to draw a hard and fast line between what ought to be collected and what ought not. The person who has a thirst for relics of criminals and murderers generally can justify his peculiar taste with a logic-and perhaps with an aggressiveness-which will make the 


\section{Introductory}

collector of objects of art think that at all events there must be something in his rival collector's hobby besides gruesomeness.

Everything is "collected" nowadays, from railway engines and men-of-war ships to animalculæ. Almost everybody collects-the poor man as well as the rich, the man with taste and artistic instinct, and the man with neither. Any attempt, therefore, at grouping the various things which are collected, or at classifying the people who collect, must inevitably fail. There are, and always will be, people who are vetera extollentes, recentium incuriosi, and who pass from youth to old age amid les infiniments petits. But who shall decide as to what is old and what is new, or as to an acceptable definition of the infinitely little? The passion for collecting is unquestionably one of the greatest safetyvalves of modern civilisation, and one of the greatest conceivable preventatives of wrongdoing. It is also unquestionably a species of selfishness, but it is a selfishness which is harmful to no one.

The antiquity of collecting is almost as great as that of the world itself. It has flourished or declined according to the state or condition of the society in which we search for it, but it has always had a tangible potency-a force which the disasters and $\mathrm{xi}$ 
falls of various nations have never succeeded in obliterating. "Why," it has been asked, "should an Egyptian of the time of Sesostris, or an Athenian in the days of Phidias, have collected the works of the barbarians? They could teach him nothing which he cared to know, and such art as they might display would have appeared to him contemptible, if not hateful." The collecting passion of the Greeks appears to have been well developed, but their acquisitiveness was rather with a view to the adornment of the temple and the agora than their individual houses. This exceedingly patriotic spirit is not yet dead, for the many national collections of objects of art, of literature, and so forth, are, to a great extent, due to private munificence. In by far the majority of instances these collections do not become public until after the owner's death-a fact which in no way impairs the value of the bequest.

A writer in the Quarterly Review for October I880, has much that is interesting to say concerning the great collectors and collections of the past. The books upon which this admirable article is founded are an anonymous work, "Les Collectionneurs de l'Ancienne Rome," I867 ; M. E. Bonaffe's book with the same title, issued in I 873 ; and "Les Arts à la Cour des Papes," 


\section{Introductory}

by Eugène Muntz, I 879, each of which is a valuable contribution to the History of Collecting, and from each of which several of the statements in this introductory chapter are derived. The reviewer points out that "the public place of many a Greek city, small in size as in most cases it was, must have had all the aspect of a museum." Even in the time of Vespasian (A.D. 9-79), 3000 statues remained at Rhodes (Pliny, xxxiv. 17), and there were not fewer at Delphi, Athens, and Olympia. It is stated that an approximate calculation of the statues and images plundered by the Romans from Greece places the number at a hundred thousand. The temples were filled with statues and pictures which had very little relation to the divinity to whom they were "offered." Although these larger objects of art appear to have been regarded as the prescriptive property of the community, it is very certain that the richer citizens were great collectors of such things as vases, engraved gems, sculptured ivories and coins, and perhaps to some extent of pictures. The four first-named species of the collector's desire were undoubtedly very keenly sought after, as many perfect and beautiful examples still existing prove beyond question.

The men of old Rome had a great contempt for collectors of objects of art. xiii 


\section{Introductory}

Cicero, in his second oration against Verres, speaks of such things as contemptible, and says that the forefathers of those whom he addressed allowed the people whom they had made tributary to retain them as an amusement and consolation in their slavery. In the "Paradoxia" (V. 2), the great orator, enraged probably at seeing that the taste for these puerilities grew and increased around him, brings forward the argument that as in a house the slaves who were intrusted with the care of the objects of art held the lowest rank, so those who passionately loved such objects were in the lowest depth of slavery. Verres, whom Cicero holds up to public scorn as the type of the selfish and unscrupulous collector, undoubtedly was one of the most celebrated collectors of antiquity, and no crime deterred him from obtaining the art treasures on which he had set his mind. Verres, as governor of Sicily, had opportunities beyond the reach of his fellowcollectors-and they loved him none the more for that. Verres voluntarily exiled himself after Cicero's first oration (actio prima) and so made any defence of his actions impossible; he, however, lived in great affluence in one of the provinces, doubtless surrounded by the magnificent collection of objects of art of which he had plundered the Sicilians. 


\section{Introductory}

But Cicero himself was not only a lover of the fine arts; he was also a collector. He ornamented his villas with statues and paintings, and is said to have spent a million of sesterces (about $£ 8000$ ) in the purchase of a table of "citrus" or thuya wood. Being a collector himself, Cicero was fully cognisant of the collector's vulnerable points, and was, therefore, the best possible "devil's advocate." We have only Cicero's attack, which is not necessarily a proof that all the charges he brought to bear against Verres are true. Verres apparently made no defence, which, so long as he retained his treasures, would be a superfluous undertaking. When the collecting hunger seizes a man, obstacles only give zest to his acquisitiveness; and this was precisely the case with Verres. Nothing came amiss to him-he " even ventured to appropriate to himself the colossal candelabrum of gold enriched with precious stones which the son of Antiochus was conveying as a present to the Republic." Verres made an ostentatious display of his various trophies. The entrance-doors of his house were those of the Temple of Minerva at Syracuse, covered with bas-reliefs in ivory incrusted with gold. His halls were filled with statues in marble or in bronze, which had been "conveyed" from the countries of Sicily, Asia, or Greece-the Cupid of $\mathrm{XV}$ 
Praxiteles, the Hercules of Myron, the Sappho of Silanion, and a crowd of other chefs-d'envre of Greek sculpture. His various collections were rich in pictures, statues, ivory, candelabra, vases, armour, engraved gems, and vessels of gold and silver-all doubtless obtained in the same impartial manner.

Cæsar also was a collector. He "was not governed by the narrow ideas of his day. His collections were not exiled to country villas; he had higher and wider views. He caused temporary porticoes to be constructed at the Capitol in order to exhibit his works of art to the public. His cabinets of engraved gems - and of these he possessed six-were sent to adorn the temple which he built in honour of Venus Genetrix ; he settled the plan of a vast library, of which Varro was to have the management; in fact, he opened to the people his fine gardens on the banks of the Tiber, and placed there his gallery of pictures and statues." It was, the Quarterly reviewer tells us, there that a fine statue of Venus was discovered in the year 1860 .

The list of Roman collectors includes many illustrious names, e.g., Sallust the historian, in whose garden the Dying Gladiator was found; Asinus Pollio, the orator, poet, historian, and friend of Augustus, xvi 


\section{Introductory}

who once owned the Toro Farnese, now at Naples; whilst even Anthony and Brutus stand before the world clearly convicted of the crime of collecting. The spirit of the collector has in reality undergone very little change during the past two thousand years. The objects of his attention have certainly greatly increased in number, and can be no longer stolen with a due regard for personal convenience; but there are still many "touches" of nature which demonstrate the uninterrupted current of human curiosity in the matter of objects of art. To both Martial and Juvenal the collector appealed with an irresistible force. We learn of Eros, who weeps because he cannot afford to buy all he sees; of Mamurra, who spends his day in examining tables of ivory, couches of tortoiseshell, murrhine cups, golden vases set with emeralds - and ends by buying two cups for a halfpenny! If a census were taken of the various types of collectors in London, it would probably be astonishing to find what a large number of Mamurrians there are! The censusmaker need not go far beyond Holywell Street, Strand : the booksellers there would supply him with enough information to fill a large " Returns."

M. Bonnaffé, in the work already mentioned, gives us a pen-picture of the conxvii 
tents of the curiosity shops in Rome when Britain was still an island of barbarians. The contents were as delightfully varied then as now, as the following inventory proves :- "Statues, pictures, bronzes of the school of Egina, made famous by Myron; of that of Delos by Polycletus; invaluable rarities of Corinthian brass, marvels of modern chasing, pieces marked with the name of Boëthius or of Mys, gigantic candelabra from the workshops of Egina or Tarentum; farther on, the shops of the engravers, the jewellers, the dealers in vessels of murrhine, of rock-crystal, of amber; delicate works in coloured glass cut on the wheel, or chased up like a piece of silver plate; chefs-d'cuvre in miniature, in ivory, in terra-cotta; the beautiful pottery of Rhegium and of Cumæ; tapestries, furniture in bronze, in ivory, in thuja, in maple, \&c."

What, it may be asked, has become of all these treasures of the ancients? Probably only one in a thousand has survived the decline, fall, and destruction of Greece and of Rome, not to mention the score of other national collapses and national disasters. A large number of those which have come down to us are only shadows of their former selves, mere caricatures of their pristine beauty. The howling demagogue, the ignoxviii 


\section{Introductory}

rant iconoclast, and the vandal to whom nothing is sacred: each of these has contributed his share to the destruction or mutilation of the works of antiquity.

When the glory of Greece became levelled into dirt and death, and the grandeur of ancient Rome became humbled, the collector suffered a collapse which threatened to prove fatal. But from the ruins there evolved a new order of things, a new race of collectors. Collecting, as a fine art, can scarcely be said to have had a great vogue until the Renaissance. "In the fifteenth century the mediæval schools of art were dying-exhausted by their very fecundity, and aged before their time. This was the hour of reaction, antiquity issues from the earth. Men were dazzled. Statues, monuments, bronzes, medals, engraved gems, fragments of ancient art-a desire to see and possess all these became general. The Renaissance is the golden age of collections."

It is to Italy, and perhaps to Italy alone, that we must look for traces of the art collector as we know him to-day. One of the earliest on record is Cardinal Giordano Orsini, who is said to have formed a choice collection of the antique things of Rome at the latter part of the twelfth century, and to have built an edifice to receive them. About a century later, Pope Boniface VIII. xix 
-better known for his disputes with the kings of England and France than as a collector-possessed fifty cameos, and doubtless other objects of art. M. Eugène Müntz, in "Les Arts à la Cour des Papes," prints. a most interesting memorandum, drawn up in I 335 by Oliviero Forza of Treviso, when about to visit Venice, in which he notes the various acquisitions of sculptures, paintings, embroideries, books, medals, designs, and an ivory chessboard, which he proposed to make in the city. And here we have a distinct and tangible reference to one of the earliest bric-à-brac hunters on record. Petrarch was a collector of MSS. and ancient medals. Pietro Barbo, afterwards Paul II., from early youth pursued the hobby of collecting with an enthusiasm and energy quite refreshing in the history of Popes. He was an ostentatious, profligate, and illiterate priest, who persecuted letters and science with a bitterness almost unparalleled. He hated the Medici even more than men of learning. That such a person should have a taste for the fine arts is a mystery, and no one has ever sustained in his favour a charge of possessing any of the finer feelings of humanity.

Paul's successor, Sixtus IV., was a disperser rather than a collector, inasmuch as he sold many of Paul's rich jewels and objects of art to the different princes of 


\section{Introductory}

Europe, Lorenzo de' Medici securing some of the treasures. The collecting passion was strongly inherent in the Medici family. Cosmo, son of the founder of the family, was an ardent collector of manuscripts in every language and on every subject; and to him is due the "Bibliotheca MediceoLaurentiana." Lorenzo, the brother of Cosmo, was also an assiduous collector, not only of books, but of works of art generally. But just as the fame of Lorenzo, the grandson of Cosmo, and known universally as il Magnifico, greatly exceeds that of any other member of the family, so did his collecting proclivities entirely outvie those of any of his relations. An entire volume would be necessary to do adequate justice to the collections formed by the various members of the Medici family. Roscoe's "Life of Lorenzo de' Medici" deals pretty fully with the subject, and it is to this work that the reader is referred for further details.

The example of this great family was enthusiastically emulated by many contemporaries. Poggio, for example, was an ardent collector. "My chamber," he says, " is surrounded with busts in marble, one of which is whole and elegant. The others are indeed mutilated, and some of them are even noseless, yet they are such as may please a good artist." Other distinguished 
Italian collectors, from the latter part of the fifteenth to the seventeenth century, include Count Balthasar Castiglione, Pietro Aretino, Don Ferrate Carlo, and Commendatore Cassino del Pozzo.

From Italy the collecting spirit passed to France. One of the most distinguished of the early collectors was Florimond Robertet, treasurer of Charles VIII., Louis XII., and Francis I. Of his collection an inventory has been published by the French Society of Antiquaries (vol. xxx.); and one of the most notable of the items is a collection of " 400 beautiful glasses of all colours, and other vessels of crystal of Venice, beautified with the prettiest conceits which the Venetian glassmakers could invent." In a curious book, quoted by M. Bonaffé in "Les Collectionneurs de l'Ancienne Rome," "Blasons domestiques pour la décoration d'une maison honneste," I 539, the author, Gilles Corrozet, describes in verse the contents of the cabinet in which were preserved both the artistic and useful treasures of the house. The lines are as follow:-

"Cabinet rempli de richesses

Cabinet de tableaux remply

Et de maintes belles ymages

De grandz et petis personages,

$\mathrm{xxii}$ 


\section{Introductory}

Cabinet paré de medailles

Et curieuses antiquailles

De marbre, de japhe et porphire.

Cabinet ou est le buffect

D'or et d'argent du tout parfaict,

Cabinet garny de ceinctures

De douvres et de bordures

De fers d'or, de estocz, de tableaulx

De chaisnes, de boutons tres beaulx

De moucherons, de braceltz,

De mux plus cher qu'or de ducat

D'ambre fin, de sauon muscat

Et parmi tant du dieurs joyaulx

Sont les riches et gros signeaulx

Les patenostres cristallines

De perles et fins rubis

Puis les mignons et bons cousteaulx

Les forcettes et les ciseaulx

Le miroir, le gente escriptoire

Le chappeau, l'eschiquier d'yvoire."

The religious and other wars which began towards the close of the fifteenth century, and ceased only at the accession of Henri IV. nearly a century later, killed for a time the collecting sentiment, which, indeed, can only live and flourish in time of peace. It was not, however, until the middle of the seventeenth century, when Louis XIV. succeeded to the throne, that it entered upon what may be termed its best period. Collectors soon became numbered not by xxiii 
units, but by scores and hundreds. At the head of them all comes Cardinal Mazarin.

The English taste for collecting objects of art was undoubtedly the outcome of foreign travel on the part of English gentlemen. The Englishman who might have been the greatest collector of his age-Henry VIII. - unfortunately developed into the greatest disperser. It is useless now to bewail the wholesale destruction or mutilation of works of art and antiquity which followed the dissolution of the monasteries. Had these objects been carefully preserved and placed in the custody of sympathetic men, the museums of this country would have been richer by far than any other in Europe. Long before this cataclysm England possessed a genuine collector in the person of Cardinal Wolsey. It is said of him that if Quentin Matsys had a picture on the easel, Wolsey was ready to purchase it; if there was a curious clock, it was secured for him. His fondness for tapestry amounted to a passion. His agents ransacked the Continent to procure choice sets of arras, new and old, for his palace. His magnificence generally is so much a matter of history that it need not be entered into here. The one redeeming feature in the public acts of Charles I. is that he was a xxiv 


\section{Introductory}

great collector, and the dispersion of his collection of works of art has been generally regarded as one of the great national calamities of the period. The Tradescants, Elias Ashmole, and other distinguished collectors are part and parcel of the history of the seventeenth century.

Sir Hans Sloane, who was born in 1660 and died in $175^{2}$, was one of the great collectors of his time, and his collections formed the nucleus of the British Museum. Sir Charles Hanbury Williams, being asked by Sir Hans Sloane to send him what curiosities he could find in his travels, sent him an amusing poetical catalogue of "rarities," of which the following is a specimen :-

"From Carthage brought, the sword I'll send

Which brought Queen Dido to her end.

The stone whereby Goliath died,

Which cures the headache, well apply'd.

A whetstone, worn exceeding small,

Time used to whet his scythe withal ;

The pigeon stuff'd which Noah sent

To tell him where the waters went.

A ring I've got of Samson's hair,

The same which Delilah did wear:

Saint Dunstan's tongs, which story shows

Did pinch the devil by his nose.

The very shaft, as all may see,

Which Cupid shot at Anthony ;

And, which above the rest I prize,

A glance of Cleopatra's eyes ;

This my wish, it is my glory,

To furnish your nicknackatory."

$\mathrm{XXV}$ 
Probably the greatest collector of the last century was Sir Andrew Fountaine, of Narford Hall, Norfolk. He was born in 1676 , and was knighted in 1699 for his classical attainments. In I70I he paid an official visit to Hanover with Lord Macclesfield, and went thence to Italy, buying anything scarce and curious which came under his notice. He succeeded to Narford on the death of his father in I707; seven years later he made a long sojourn in Paris, going thence to Italy, and spending nearly three years at Rome and Florence. In 1727 he succeeded Sir Isaac Newton as Master of the Mint. His collection, which was considerably augmented by the late Mr. Andrew Fountaine, who died in 1873 , comprised the rarest and most beautiful works of cinquecento ceramic art ever formed by a private individual, many of the examples being absolutely unique. The sale of this magnificent collection at Christie's in 1884 realised a total of $£ 96,278$, whilst a further portion of the collection produced nearly $\&_{1} 5,000$ in July I 894 .

Horace Walpole, who was born in 17 I 7 and died in 1797 , was a very celebrated collector of objects of art, and is said to have formed his passion for the Fine Arts while in Italy on the Grand Tour. It was not until April 1842 that the contents of Strawberry xxvi 


\section{Introductory}

Hill were sold by auction; the proceeds of the sale, which lasted twenty-four days, amounted to over $£ 33,45^{\circ}$. In no respect, however, can Horace Walpole be compared to William Beckford,-either as a man of taste or as a collector. Beckford was an excellent scholar, and possessed a fine judgment of almost every branch of art. He formed one of the choicest and most extensive libraries in England, and his galleries of pictures and antiquities were almost unequalled. In May I 844 Phillips, of New Bond Street, sold a quantity of furniture, \&c., from this collection, the amount realised by a thirty-seven days' sale being over $£ 80,000$. The sale of his library, in I882-83, realised over $£ 86,000$.

Ralph Bernal formed a collection of articles of rare excellence, and of an age exceedingly rich in ornamental art, extending from the Byzantine period to that of Louis XVI. At the dispersal of this collection in 1855 , some extraordinary prices were realised, which have been attributed to the artistic character of the articles themselves, rather than to their extrinsic value as historic relics. Mr. Bernal's collection had a world-wide celebrity, and his judgment was acknowledged all over Europe. In a few introductory lines to the catalogue of the sale, J. R. Planché thus speaks of the xxvii 
friend with whom he had been associated for thirty years:- "Distinguished among English antiquaries by the perfection of his taste, as well as the extent of his knowledge, the difficulty of imposing upon him was increased by the necessity of fabrication being fine enough in form, colour, or workmanship to rival the masterpiece it simulated-to be, in fact, itself a gem of art, which it would not pay to produce as a relic of antiquity." The entire sale realised close on $£ 7$ I,, 00 . Very many of the articles sold for far more than Mr. Bernal had paid for them-a proof not only of his skill as a collector, but as showing that the purchase of articles of vertu, guided by correct taste and judgment, generally proves a very profitable means of investment. For instance, about 400 lots of Majolica ware, which cost Mr. Bernal Iooo guineas, realised at his sale upwards of $£ 7000$; Sir Thomas More's candlesticks, bought by Mr. Bernal for twelve guineas, realised 220 guineas; King Lothaire's magic crystal, bought by Mr. Bernal for ten guineas, sold for 220 guineas. Many similar instances might be quoted.

During the last few years a number of celebrated collections of works of art have come into the market; first and foremost, the Hamilton sale of I 882 , when, 22 I 3 lots xxviii 


\section{Introductory}

brought a total of $£ 397,562$, or about $£ 100,000$ more than was anticipated by those best qualified to judge. The BeckettDenison collection of I 885 realised close on $£ 70,000$, a total which, as a whole, shows a very great loss on the original outlay. The renowned collection formed by the late Hollingworth Magniac realised, in July I 892 (eleven days' sale), the large sum of \& 103,000 . But the particulars of this and many other recent sales of famous collections of works of art are too easily accessible to require any further reference in this place.

Collecting has long since taken its stand as a fashion-to what extent, indeed, may be gathered from the fact that during the past season the gross proceeds of the sale of objects of art at one place in London is understood to be about $£ \mathrm{I}, 000,000$. It will be inferred from this that the hobby of collecting is one that requires a wellfilled pocket. That is undoubtedly true so far as the chefs-d'cuvre of the various objects of art are concerned. But much good sport, and an infinite variety of charming and interesting, as well as decorative, objects of art may be acquired at a very small cost by the collector who possesses a fair share of taste-and commonsense. 



\section{Rare Books}

\section{and their Prices}

THE origin of the English taste in books is to be sought out of England, where our forefathers found it imperative during many centuries to go in order to complete, not only their accomplishments, but their education. The schools and academies of the Continent provided English gentlemen with the culture which they were long unable to obtain at home, and with the culture naturally came the feeling for the books which were collected by Italian, German, and Hollander. These were mainly the Classics, and at first the insular purchaser satisfied himself with the current editions produced at Amsterdam, Leyden, Antwerp, or Leipsic. But of course there arrived a season when certain more inquisitive or enthusiastic minds began to call for the texts which sprang into existence at the dawn of typography, and united with their literary pretensions archæological claims. Collectors kept their standard 


\section{Rare Books}

editions for use, and bought editiones principes as curiosities and treasures. The demand for the Greek and Roman writers was wide and lasting; that it was not more so, was due in large measure to our universities and to men who had received university trainings. In the earlier half of the last century, Englishmen are found turning for the first time seriously to the consideration of the question whether, beside the foreign classics, England and Scotland had none of their own. The movement may be thought to have commenced through a sentiment of which the germ is traceable to such spirits as Jonson and Dryden in a prior age in favour of the neglected genius of Shakespear, while a Dutch Elzevir cost forty times as much as a first quarto, and an edition of the Fathers was worth more than all the early English poets.

It was such men as Sir Thomas Hanmer, Theobald, Pope, Steevens, Malone who fostered the tendency to turn to the authors born on English ground, the predecessors and contemporaries of the Stratford bard, and to treat the ancient verse and prose writers as a subsidiary feature in their libraries, if not in their thoughts. But the yet more powerful influence, perhaps, in winning round our countrymen to a study and appreciation of their native literature, was the appearance 
about I 20 years ago of Warton's "History of English Poetry," a work in many respects imperfect and unsatisfactory, as we view it to-day, but which nevertheless opened the eyes of thousands by degrees not merely, not even so much, to the beauties of the English school, but to the existence of such a thing; and what a marvellous change came over us from that time forward! Warton, in addition to his account of our poets, incidentally referred to our typographical monuments and to the precious MSS. which our public and a few private libraries possessed; and then there was Joseph Ames, who in I 749 gave to us his "Typographical Antiquities," another stimulus in the same direction, and another blow to the foreign classics.

We are just working in bare outline. We wish simply on the present occasion to point out some of the phenomena and motives attendant on the modern modes of bookcollecting, where men of fortune, men of rank, men of business, emulated each other in forming libraries, from which the classics were not excluded, but where due homage was paid to the vernacular literature of England. Such were James West, Topham Beauclerk (Johnson's friend), Major Pearson, the Duke of Roxburghe, David Garrick, George Steevens, the Rev. Jonathan Boucher, among hundreds of others belonging to all walks of 


\section{Rare Books}

life. Above and beyond them all towered the incomparable Heber, not only a collector and bibliomaniac, but a scholar and a reader of what he bought-a man who, from about I 810 to 1833 , absorbed everything within reach or to be got for money, and some of whose acquisitions constituted the gems and stamina of the Miller and Daniel collections. The histories of the more recent libraries in England are for the most part genealogical; a certain number of unknown books or editions have been brought to light since Heber's time, but in turning over the pages of the Corser or Huth catalogues, for instance, you see clearly enough that the provenance is the same; the books are in other keeping; and in the case of the Britwell collection it is not too much to affirm that it is what it is principally by virtue of Heber.

The greater part of books do not die, but exist in a state of suspended animation, while they happen to be the class of literature for which the rulers of the market are not immediately calling. As with old china and old coins, the danger is that a more or less prolonged interval of neglect may involve the partial destruction of a not very large surviving residue, and that when the passion for the love of other days at length returns, the means of satisfying it are more limited and the number of competitors more con- 
siderable. Yet this condition of affairs ought not to be unwelcome to the true bibliomaniac; it should suit him down to the ground. The only exceptions to the freedom of old books from mortality are to be looked for in the regions of science and theology; and there the form often conspires with the subjectmatter to harden the hearts of men against a restoration to favour. Volumes in folio, though they be of that mitigated type called pot, require a very powerful brief to save them from the kitchen-grate or the paper-mill.

We have it on the authority of Leonard Fairfield's friendly bookseller in "My Novel" that " those who buy seldom read," and there can be very little doubt about the fact that the collector's reading does not often get beyond what printers term the "preliminary matter." His disinclination to read is, however, to be regarded as a virtue, as, if in times past the fraternity had been consumed with a craze for reading as pronounced as that for acquiring, there would be no fine or spotless copies of anything now in the market. Who would at present think of reading a perfect Caxton, a first quarto Shakespear, or even an editio princeps of "Modern Painters"? We can get all we want out of facsimiles or cheap reissues. It is a sufficient satisfaction to reflect that the books we collect were at one time readable. 


\section{Rare Books}

The motives of no two collectors are precisely identical. The object may be every known publication of certain authors or subjects, and the aim may either be commercial or intellectual. Speaking generally, the specialist who rigidly adheres to one phase does not exist, for when once a man has been bitten with the incurable disease of book-collecting, he does not take up one subject without trenching upon at least a dozen others. But every collector, whatever his particular weakness, has a sneaking regard for a black-letter book, a tall copy, an Elzevir - when it is of the "right" date -and for an editio princeps when it is to be had cheap. (Even Mr. Gladstone himself has confessed to a weakness for a tall copy.)

Again, two men may each form a collection on lines as nearly as possible identical, and yet the intellectual results may bear no comparison one with another. The books of the one may have no extraordinary interest, while those of the other may possess marks of distinguished previous owners, or may have been bound by an eminent binder, or be copies perfect down to the minutest particular. There is a very subtle difference between a tall copy and a short one, as the owner quickly finds out when he wants to sell; and in the case of "Paradise Lost" it has been dis6 


\section{and their Prices}

covered that no less than nine different titlepages were issued with the first edition in the course of three years. It would seem that the sale of "Paradise Lost" was exceedingly slow, and the publisher could only work off the stock at considerable intervals, each new bookseller naturally demanding a fresh title-page; hence the number of issues of the first edition. Fortunately this is a very unusual contingency even in the history of rare books, for many examples of this kind would render bookcollecting an almost impossible hobby.

The reproduction of first editions not long since became a trade, and a somewhat prolific source of trouble to the novice in bookcollecting; whilst facsimiled leaves have the questionable merit of too closely resembling the missing ones, and make all the difference in the value of the book.

The dispersion during the past ten or a dozen years of several of the most famous private libraries in England has more than sufficiently emphasised the vast difference between books with and books without firstclass bindings. The Beckford and Sunderland collections may be cited as examples in each class respectively; but they are both extraordinary illustrations of the value of books when collected with discrimination. The Sunderland Library was formed in about twelve years, at a time-the beginning of 
the last century-when books which are now almost priceless were to be had for very small sums. It came under the hammer, at Messrs. Puttick \& Simpson's, between December I 88 I and March I883, occupying fifty-one days, and showing a total of $£ 56,581,6 \mathrm{~s}$. for about I 4,000 lots, or an average of just over $£ 4$ each. The majority of these books were in anything but first-class condition, chiefly from the fact that, for over a century after being stored in the library at Blenheim, they had been subjected to the devastation of a scorching sun beating down upon their backs through the huge windows, and had been so completely undisturbed that birds had built their nests behind the rows of volumes. A provincial binder, moreover, had in many instances exercised his depreciatory influence on the margins, not content with spoiling the exteriors. Apart from these very serious drawbacks, the insides of the books were perfectly clean. The average, and consequently the total, would have been far higher, had the volumes been in a better state of preservation.

At the Beckford sale, at Sotheby's in I 882-83, 9837 lots, spread over a period of forty days, realised a total of $£ 73,55$ I, I8s., or an average nearly double that of the Sunderland collection. Beckford's books were often splendidly bound, many having the devices of kings, queens, and other distin- 


\section{and their Prices}

guished previous possessors. Indeed, Beckford neglected no opportunity or expense in obtaining books with pedigrees, and their value was perhaps enhanced by the piquant or sarcastic notes which this distinguished collector made on the fly-leaves of the greater number of his books; for Beckford was an omnivorous reader, and at the same time the author of "Vathek" and a man of fortune. But the value of rare books, finely bound, was still further emphasised in the Syston Park Library. This, coming under the hammer at Sotheby's in I884, and consisting of about 2000 books, realised a total of $£ 28,000$, or an average of $£ 14$ each. Sir John Thorold began to collect books during the last quarter of the last century, and his fine judgment and exacting taste have been very amply vindicated. His bindings included specimens by the two Eves, Le Gascon, Monnier, Dusseuil, Boyet, Padeloup, Derome, Roger Payne, and others. The Syston Park sale has been described as the high-water mark of English book-collecting, and this judgment may be accepted as generally correct. But the average is not the highest, for the total amount of the five days' sale of Baron Seillière's library at Sotheby's in February I 887 brought the average up to about $\&$ I 6 per book-I I 47 lots realising $£$ I 5,000 . This is the highest average of any book sale. 


\section{Rare Books}

This library consisted of the finest collection of early romances of chivalry and ancient French literature which has ever come into the market, to which may be added that the exquisite taste displayed in the binding of these books surpassed anything of the kind that has ever come before the public notice. The Grolier books in particular fetched very high figures.

As a contrast-undoubtedly an extreme one-to the foregoing libraries, the sale of the first two portions of the stock of the late Mr. Stibbs, bookseller, may be cited. In eleven days during I 892 Messrs. Sotheby disposed of lots which would show an aggregate of about 50,000 volumes, with a net result of $£ 3034,15 \mathrm{~s}$. This stock was almost exclusively made up of old books which at one time formed the general run of private libraries; many of them were once much sought after. But a fairer case of comparison undoubtedly occurs in the recent sale of the Apponyi Library, which, formed at the beginning of the present century by an accomplished scholar, Count Antoine Apponyi, of Nagy Appony, Hungary, was transferred from that place to Messrs. Sotheby's rooms in London. In five days in November 1892 , I 359 lots realised a total of $£ 3364$, or rather less than $£_{2}$, IOs. each. Identical editions of many of the books in this sale occurred 


\section{and their Prices}

also in the Beckford and Syston Park libraries, and an analysis of the prices realised at the three sales would appear to demonstrate a lamentable fall. But this is more apparent than real, for the examples of fine bindings in the Apponyi Library were exceptionally few, and could bear no comparison with those in either of the other two collections.

As a general rule, the editiones principes do not sustain their old market value; but a certain few, particularly the most ancient typographical monuments, and some of the important classic authors produced at Naples and elsewhere before 1470 , evince a tendency, at all events, not to recede. It must be admitted that there is something superlatively attractive in a first edition, coming, as it does, fresh from the author's mind, or as a first triumph of typographical effort. The very first works of the earliest printers have never been excelled in the beauty of their execution, and they will for all time stand as an incentive as well as a reproach to modern printers. It is of these incunabula and other early printed books that many of the great private English libraries have been composed. The Sunderland Library, for example, contained a bewildering numberthere being an editio princeps of nearly everything worth having, and a series of other early editions, each of which possessed 
some special feature. To take a few illustrations: there were 85 editions of Aristotle, 40 of St. Augustine, 75 of Ovid, 71 of Petrarch, 45 of the elder Pliny, 79 of Homer, and $\mathrm{I} 8 \mathrm{I}$ of Horace.

The Mazarin Bible, printed by Gütenberg and Fust circa I 450-55, may be taken as an extreme instance of the enhanced value of the editiones principes. At the Perkins sale in 1873 , the only vellum copy then known outside a public library sold for $£ 3400$, whilst a copy on paper fetched $£ 2690$. At the Thorold sale a magnificent example on paper realised the extraordinary sum of $£ 3900$, or $£ 500$ more than the vellum one; in 1889 the Hopetoun copy, which was slightly damaged, sold for $£ 2000$; and in March I89I the Ives copy, with fifteen leaves in facsimile, for 14,800 dollars. In a book of this sort the slightest stain or incompleteness of any kind makes a difference of hundreds of pounds.- But up to and including the first quarter of the present century its price rarely exceeded $£ 100$, and the highest figure was 6260 francs paid for the $M^{\prime}$ Carthy copy, whilst the Gaignat copy on vellum only realised I 200 francs in 1769 . The first edition of the Latin Bible with a date, printed by Fust and Schœefer in 1462 , may also be cited here. The Gaignat copy on vellum, sold in 1769 for 3200 francs; the 


\section{and their Prices}

Edwards copy, also on vellum, in I 8 I 5 for $E_{175}$; in 1823 a very fine example reached $£_{21} 5$; in 1873 the Perkins copy (which had cost its owner $£ \mathrm{I} 73$ ) sold for $£ 780$, and eight years later the Sunderland example, on vellum, was knocked down for $£ \mathrm{I} 600$. A still more notable illustration occurs in connection with the Psalmorum Codex, printed by Fust and Schœffer in 1459, and this is remarkable as having been acquired by Mr. Quaritch at the highest sum ever paid for a single book, viz., $£ 4950$. It is the second book printed with a date, and is undoubtedly the grandest specimen of the typographic art in existence. It is one of the rarest of the early monuments of printing, and beside it the Mazarin Bible is a comparatively common book; its rarity will be clearly understood when it is stated that this copy, which belonged to Sir John Thorold, is the only one that has occurred in the market. It sold for $335^{\circ}$ francs in the $M$ 'Carthy sale, for $£ \mathrm{I} 36$, Ios. in that of Sir M. Sykes, and it still remains, we believe, in Mr. Quaritch's hands. Another of the earliest printed works may be here cited : the Catholicon, I460, one of the few indubitable productions of Guitenberg's press, and for which Sir John Thorold paid $£ 65,2 \mathrm{~s}$; it realised at his sale no less than $£_{400}$.

The editions of the English Bible printed 


\section{Rare Books}

during the earlier half of the sixteenth century maintain high prices, but anything like a fair comparison is difficult, as the copies which have come under the hammer during the last fifty years vary very much in the degree to which they are imperfect. The theory that reading a book sometimes becomes a deadly sin, assumes a very practical form in connection with the early English Bibles; and the extreme rarity of perfect copies is the best-or, in the eyes of the collector, the worst-possible proof of its extreme popularity with our forefathers as a book to read. The editio princeps of the complete English version, I 535, realised $£ 400$ at the Perkins sale, and was presumably perfect; an example with eight leaves facsimiled, but offering one of the finest specimens of Bedford's bindings, is now priced at $£ 300$; but an absolutely complete example would probably bring over $£$ I000.

Among first editions of secular books the Valdarfer Boccaccio of I47 I stands well in the front rank. Of this excessively rare book only one perfect copy is known, and there are less than half-a-dozen imperfect ones in existence. At the Roxburghe sale in 1812 the enormous sum of $£ 2260$ was paid for a copy of this book by the Marquis of Blandford. Seven years afterwards the same copy went for $£_{918}$, I 5s. Even 


\section{and their Prices}

this figure is extremely high. It cost the Duke of Roxburghe roo guineas. A copy, the tallest known, but with five leaves missing, and several others mended, sold in March I 89I for $£ 230$. Almost as rare as the Valdarfer Boccaccio is the first edition with a date of Virgil, printed by Vindelin de Spira at Venice in 1470, the Sunderland copy of which now figures in a catalogue at frooo, while the Ives copy was knocked down in I $89 \mathrm{I}$ for 3000 dollars-both being printed on vellum. Just a century ago, in the Crevenna sale, a copy of this fetched 4I 50 francs, but for nearly fifty years afterwards the few copies that turned up only realised about half that amount, and in one instance it went as low as I 301 francs. Equally splendid, from a typographic point of view, and equally interesting, though by no means so rare, is the first edition of Homer, printed in Greek at Florence in I488. The Duke of Grafton's copy sold in 1819 for $\& 69$, and the highest figure paid for one until lately was 3601 francs for an uncut copy in the Cotte sale, I804. The copy-one of the finest in existencefor which Mr. Wodhull paid 15 guineas in I 770 , realised $\delta_{2} 00$ at the sale of his library in I886. The first edition of the first book printed in Greek-the Grammatica Graca of Lascaris, Milan, 1476, of which only 


\section{Rare Books}

about six copies are known, was sold at the Heber sale, 1834, for the then high sum of $£ 34$, whilst in the half-century which followed its value had increased threefold, the Thorold example going for $£$ io5. It is one of the rarest books in existence, and in the preface to the Aldine edition of I 494 it was even then stated that "no copies of this edition could be procured after the most diligent search." Dr. Burney's copy of this valuable book is now in the British Museum. The first edition of Ovid, printed at Bologna, I47I, is perhaps the rarest of all the editiones principes of the classics, only one perfect copy being known, and even the odd parts or volumes of this shew a marked increase in value during the past few years. The first edition of Pliny's Historia Naturalis, Venice, 1469, of which the Thorold copy sold for $£ 57$, is far more easy to obtain.

It is one of the phenomena in the annals of book-buying that the productions of the Aldine press, unless they are on vellum or of some special character, should have at all declined in popularity. The first edition of the first book printed by Aldus, the Musai Opusculum de Herone et Leandro, Venice, I494, is worth from $£ 36$ to $£_{42}$; fine copies rarely occur in the saleroom, but, curiously enough, it is usually 


\section{and their Prices}

in good condition: here, again, the virtue of the non-reading collector comes out in bold relief. It is very different with the first edition of the Aldine "Virgil," I 501 , notable as being the first book printed in italic characters: it is practically impossible to obtain a perfect copy, both the Beckford and the Hamilton examples being incomplete; a very good example is priced at $\delta$ I55 (the Ives example, which was perfect, only fetched 250 dollars), about one-fourth the value placed upon it a quarter of a century ago. The $H y p$ nerotomachia Poliphili, printed by Aldus in I499, is sought less on account of its typographical than its graphic interest, the engravings being of a peculiar type, which recommends it to the collector. In this case the tendency is distinctly an upward one. Condition being everything, the copies sold during the past few years shew considerable fluctuation; but a very inferior copy now realises four times as much as a perfect one fifty years ago, when several, by no means poor copies, changed hands for $£ 5$ each. Mr. Quaritch tells us that the copy for which Mr. Cheney paid him $£ 45$, sold six or seven years after for $£$ II 9 ; the Beckford realised $\&^{\mathrm{I}} 30$, and the exceptionally fine example in the late R. S. Turner's library sold for $£$ I 37 . 


\section{Rare Books}

Notwithstanding the perhaps permanent fall in the estifnation of normal Aldines, that of exceptional copies is unaffected. For example, ten or twelve guineas would be a fair price for the first Aldine "Lucretius," I 500, but Grolier's copy of the second edition realised, a few years ago, $£ 300$. The difference is purely external, and to a great extent abstract, but it is there nevertheless.

It is the same with the Elzevirs. Even the "best" editions of these frightfully inaccurate but delightful little books are now at a lamentable discount, and with only their past reputations to commend them. In January 1890 a parcel of twentysix Elzevirs realised a less average than Is. each. Almost the only exception to this general downfall is Le Pastissier Francois, I 665 (of which about forty copies are known), of which, in 1780 , a copy sold for 4 francs; in I8I9 the Marlborough example went for $£ \mathrm{I}, 4 \mathrm{~s}$. ; in 1828 Sensier's realised I 28 francs, and nine years later 201 francs; then the old vellum binding was substituted for a very beautiful covering by Trautz-Bauzonnet, and in 1870 it brought 2910 francs; and then, five years later, in the Benzon sale, it advanced to 3255 francs. But in 1877 , when it once more came into the market, it fell to 2200 francs. The 
highest price paid for Le Pastissier is I0,000 francs, at which absurd sum it was sold a few years ago in Paris.

Turning from books issuéd in foreign countries to those of a more immediate English interest, the works of Caxton naturally come first. There are about 560 examples in existence of England's first printer. Of this number about four-fifths are in the British Museum, at Cambridge and Oxford, in the Duke of Devonshire's and the Earl of Dysart's libraries, and in the Rylands (olim Spencer) collection at Manchester. Out of this total thirty-one are unique, and seven exist only in a fragmentary form. It is obvious, therefore, that whatever changes may occur in the fashion, Caxtons cannot be expected to decline in value. The prices at which these books have been sold at different times afford some striking comparisons. At the Watson Taylor and Perry (Morning Chronicle) library sales in 1823 , five examples, nearly all fine copies, of Caxton's books realised a total of $£ 29 \mathrm{I}, \mathrm{I} 5 \mathrm{~s}$. These books were "The Life of Jason," I 476-77 (£95, I Is.), "The Book called Caton," I483 (£30, 19s. 6d.), "Troylus and Cresside," $\mathrm{I}_{484}(£ 66)$, and a very fine and perfect copy of Virgil's "Eneidos," I 490 ( 46, $_{4}$, I 4s. 6d.). Of the first two there are only six copies of each known; of the third, 
twelve examples; of the fourth, four copies, and of the fifth eighteen copies. There are no available records of any of the first four having been sold during recent years, and it is curious to note that of the least rare, the "Eneidos," Mr. Quaritch priced a copy in 1877 at $£ 300$. Although the increasing value of Caxtons is a fact which does not need much demonstration, it will be of general interest to quote a few more illustrations in this connection. The highest sum ever paid for a Caxton is ¿1950, at which the Harleian copy, and the only perfect one known, of "King Arthur," 1485, was knocked down at the sale of Lord Jersey's books in I885. Unfortunately, and to the lasting disgrace of England, it was secured by an American collector, whose widow, Mrs. Pope, has since parted with his books more viduarum. At the same sale one of twenty examples (of which only three are perfect) of the first book printed in English, the "Histories of Troy," realised $\mathrm{E}_{1820}$; in 1812 the Duke of Devonshire gave $£$ 1060, I2s. for a copy wanting the last leaf, which had belonged to the queen of Edward IV., and for which the Duke of Roxburghe had paid $£_{50}$ a few years previously! In 1885 a very imperfect example of Higden's Polychronicon, 1482, realised the high figure of $£ 66$, but $\mathrm{Mr}$. Quaritch 


\section{and their Prices}

values the best of the three perfect copies known at $£ 500$; the Perkins copy sold in I 873 for $£_{36}$, but the same example appears to have depreciated slightly in value by crossing over to America, inasmuch as it only realised 1500 dollars at the Ives sale in I89 I. In I 868 the Rev. T. Corser's copy of the "Dictes and Sayings," I 477, the first English book which bears a plain statement of place and time of its execution, sold for EIIO; the Earl of Jersey's copy in 1885 fetched $£ 350$, whilst the Duke of Buccleuch's copy, four years later, sold for $£^{6} 5$. Neither of the first two was complete. "The Mirrour of the World," I48 I, of which only sixteen copies are known to exist, is also a book which shows a steady rise in value. The Duke of Devonshire's perfect copy many years ago cost $\AA_{35}$ I, I 5 s., whilst the Syston Park example, which was not quite perfect, sold in 1884 for $£ 335$. The same may be said of " one of the rarest and most intrinsically valuable" of Caxton's productions, Gower's Confessio Amantis, I 483 , of which only five perfect (and twelve imperfect) copies are in existence, and of these Lord Selsey's, in old calf binding, in I 872 fetched $\$ 670$, and Lord Jersey's in I885, $£ 8$ ro. A copy, imperfect only to the extent of having one leaf in facsimile, is catalogued at $£ 380$. Lord Chancellor 


\section{Rare Books}

Hardwicke's imperfect copy of the "Game and Playe of the Chesse" sold in 1884 for $£ 260$; a century ago a perfect example was purchased for $£ 30$, os. $6 \mathrm{~d}$.

The works of Shakespear, so far as the original quartos and folios are concerned, yield to no other in their advance in price among book-fanciers; at the time of publication theformerwere obtainable for a few pence. At George Daniel's sale quartos which had cost $£ 40$ realised between $£ 300$ and $£ 400$. But even at the Steevens sale in I 800 there was a foretaste, amid low figures given for many distinguished rarities, of what was coming, and of what we still feel and see. The same upward tendency is witnessed in regard to the folios. A fairly good example of the first, published under the editorship of Heming and Condell in 1623 , might have been had fifty years ago for under $£ 30$; a fine copy at the Roxburghe sale, I 8 I 2 , went for $f$ roo, just a fifth of what many collectors to-day would give for a similar one; the Thorold example (1 $3 \frac{1}{8} \times 8 \frac{1}{2}$ inches), was one of the largest and finest known, and it sold for $£ 590$. A bookseller has priced "a matchless copy" at $£$ I 200. Mr. Locker-Lampson's is an equally splendid copy, and is scarcely inferior to that in the possession of the Baroness Burdett-Coutts. Quite the finest example known up to the present is 


\section{and their Prices}

in possession of Mr. C. J. Toovey, it being both broader and taller than any recorded copy, whilst very many of its leaves are absolutely uncut. The second, third, and fourth folios are also relatively dearer. The second, dated 1632, varied, till within the last twenty-five years, between $£ 5$ and $£ \mathrm{I} 5$, at which latter sum the Roxburghe copy was knocked down. Two examples (neither absolutely correct), which have occurred in the last two seasons, were the Cosens, $£ 62$, and the Ives (New York), 400 dollars. The third folio, I664, which is really the rarest, sold forty or fifty years ago for about $£ 20$ or $£ 30$; the Ives copy, which formerly belonged to John Philip Kemble, brought 950 dollars; and another, Mr. Gaisford's, went for $£$ I68. A copy was sold at Christie's in June 1894 among Sir J. Hay Langham's books. The seven doubtful plays, which are usually omitted in copies of the first issue, were at the end of the copy in question, and were preceded by the title, dated 1664 ; its height was $13 \frac{3}{8} \times 8 \frac{7}{8}$; and it realised the record price of $£ 435$.

Perfect copies even of the fourth folio, I685, which at one time could have been had in plenty for $£ 5$, and which is of no special interest or value, have sympathetically risen, the Gaisford copy realising $£ 62$, and the Ives 210 dollars. 


\section{Rare Books}

Of the miscellaneous early English writers, especially those of high rank, the value is at present far higher than it used to be, partly from the augmented competition for a limited supply. The earliest issues of Spenser and Milton, for instance, have more than quadrupled in value within a few years. In some instances this has been exceeded in a few months. In June I 889, a copy of the extremely rare first edition of Richard Lovelace's "Lucasta," I649, sold by auction for $£ 6$, I2s. 6d.; in May I 892 another example realised $\mathcal{L}_{44}$, and both possessed all the beautifully engraved plates. It is the same with the earliest impressions of Walton's "Compleat Angler," I653. Referring to a catalogue published by Mr. Quaritch in 1879, we find a fine copy in red morocco extra priced at $£_{52}$, with an apologetic footnote to the effect that it is twenty years since a copy " last occurred for sale," excepting the copy which was included in the set of five editions sold at Tite's sale for $£ 68$, and afterwards at Crawford's for $£ \mathrm{I} 00$. Of that set, the first edition constituted fully threequarters of the entire value. In I 889 one realised $f \mathrm{I} 80$, and in $\mathrm{I} 89 \mathrm{I}$ another (with which went Cotton's "Complete Angler," I676) for $£ 310$, and a third in May 1892 for $£ 2$ ro.

Certain eighteenth-century books fetch 24 


\section{and their Prices}

even more in proportion. The first edition of Goldsmith's "Vicar of Wakefield," I766, a quarter of a century ago could have been purchased for $£_{5}$; eight or nine years ago almost twice that sum would not have been considered excessive; in I89I a copy sold at Sotheby's for $£ 90$, and in May I 892 another at the same place went to 694. Gray's famous "Elegy," I75 I, which was originally sold for sixpence, jumped from $£ 36$ in 1888 to $£ 59$ in 1892 , and when the next copy came into the market in December I 893 it sold for $£ 74$. The first editions of Fielding, Smollett, Sterne, Swift, and Defoe, (in "Robinson Crusoe" the set of three volumes should be all of the first edition and in good state) are good or bad investments just as they happen to be acquired. The "curious" class of printed matter in which the last century was so prolific is in fairly great demand just for the moment, and notably the memoirs, real or imaginary, of some only too well-known actor or actress. As an example, "The Memoirs of his Life," by Theophilus Keene, I718, sold for $£$ I 7 in 1889 , whereas a quarter of a century ago George Daniel's copy did not realise many more shillings. The "Memoirs" and the "Apology for her Life," I785-86, of Mrs. G. A. Bellamy, or the "Authentick," as well as the "Faithful" Memoirs, I730-3I, of Mrs. 


\section{Rare Books}

A. Oldfield, and similar records are "placed" at high prices.

A development of another kind is in "Americana." As a country gets richer its taste for the extraneous attributes which go to make life worth living becomes more and more pronounced. This taste has been fostered in the true scientific manner by such distinguished bibliographers as the late Henry Stevens of Vermont and by such liberal patrons as the munificent founders of the Lenox and other libraries. For anything of real or supposed importance relating to the country Americans will pay a fair price; but London is the next best market for "Americana." Indeed, periodical consignments of rare books, including "Americana," are shipped to London for sale. Very many incidents of the greatest interest might be cited in connection with this development, but there is space for one only, as indicating the high and low water marks. This occurred when the books of the late Lord Chancellor Hardwicke's library were sold at Christie's in I 888 . Among others there was an unprepossessing small quarto volume consisting of a dozen tracts bound up together. These tracts chiefly related to American affairs, and were published in London between 1583 and I657; and the lot was knocked down for the extraordinary sum of $£ 555$. On the other hand, 


\section{and their Prices}

in 1886 the Somers tracts in 30 folio volumes, containing some of the rarest "Americana" in the finest state, fetched only $£ 6 \mathrm{r}$. There is no class in the world who in one respect more implicitly obey the Scriptural injunction, "Look unto the rock whence ye are hewn, and to the hole of the pit whence ye are digged," than the Americans. Fortunately they are in a position to pay for it. For many years past American collectors have been draining England of rare books and manuscripts, and more particularly of works relating to British genealogy and county history.

The changes which inevitably occur in every line of life, intellectual and material, are also extended to book-collecting, and extended in a very marked and significant manner. The old loves have to a certain extent been abandoned, and the new generation has gone in heavily for the first editions of modern authors.

The attraction of a first edition over the second or subsequent issues falls into the category of things which are not explainable on ordinary principles. The charm is so much a matter of feeling, that any attempt to justify it can nearly invariably be seized upon and used, or rather turned against it by the utilitarian. Book-buying has been described as one of the few 


\section{Rare Books}

passions which require neither apology nor defence; and of all the many attempts which have been made to excuse this most fascinating hobby, we have never yet come across one which has either satisfied the collector or silenced the Philistine. We do not propose, therefore, attempting a justification which could readily be converted into a condemnation. The cult of first editions has nevertheless many tangible and logical reasons which may be urged in its favour, so long, of course, as the cult is not carried to excess. A first edition often possesses an attraction which is much more than sentimental, for the very paper on which it is printed may be no longer manufactured, the type used in its composition may be no longer in vogue, and the cover in which the book is bound may have been manufactured out of a material which is not only gone out of fashion, but which is no longer possible to procure. These attributes, singly or combined, are naturally esteemed as bringing our sons or grandsons nearer than any amount of written description to our own "old" times. Even the old divines are tolerable in their quaint typographic dress of two or more centuries ago: the "Pilgrim's Progress," " Paradise Lost," "Gulliver's Travels," and Walton's "Compleat Angler" are positively intolerable in their modern 28 


\section{and their Prices}

disguises; they are, indeed, as offensive to good taste as a very old man rigged out in the most modern of $f(n-d e-s i e ̀ c l e ~ d r e s s$, and aping the manners (such as they are) of a period with which he has absolutely nothing in common. A writer in the Speaker has described the "mania" for first editions as a "purely spiritual joy," and, as with all spiritual joys, the experience thereof is a thing of feeling and not of argument.

The first editions of Dickens and Thackeray are no longer the rage of the collecting public, and their decline to what may be termed a common-sense value is a matter for congratulation. The first editions of these authors now realise very high prices when they possess some extraneous matter. It makes a wonderful difference, for example, whether they possess the printed covers and the advertisements of the original parts, or whether they are minus these things.

If a copy of "Oliver Twist" possesses the cancelled and the substituted plate depicting Rose Maylie, Oliver, and others sitting in front of a fire-a plate which appeared in a few copies of the earliest issue of the third volume-the result, when it comes to selling, will be very different from what it would be without that plate. The Memoirs of Joseph Grimaldi, edited by Boz, is quite a different book in the eyes of a collector when 


\section{Rare Books}

the plate of the "Last Song" is with the pantomimic figures round the etching. So also in the case of "Martin Chuzzlewit," of which the more valuable copies of the first edition have the transposed $\&$ in the reward on the engraved title. The first edition of "Pickwick" may be taken as an illustration of the intricacies of the science of editiones principes. The "Pickwick Papers" originally came out in twenty shilling monthly parts, commencing in April i 836, and ending in November of the following year. After Seymour had etched seven plates for this work he committed suicide, and the task was committed to Buss, whose two plates, "The Cricket Match," p. 69, and "Arbour Scene," p. 74, were not considered satisfactory. Hablot K. Browne then took the place of Buss, and etched thirty-six plates, so that the total number of illustrations amounts to forty-three, to which are frequently added the Buss plates just mentioned, though they only appear in the earlier copies of the third number. While the parts were in course of publication, the author addressed several communications to his readers, and these are found in Numbers 2, 3, IO, and I 5 ; these addresses are an important item in the makeup of a genuine first edition. Good copies of "Pickwick" in the original being scarce, care must be taken to see that the contents 
are in every way perfect, special attention being directed to the plates. The first seven of these are, as already pointed out, by Seymour, the following two (in a few numbers of part 3) by Buss, and the remaining thirty-six by Hablot K. Browne, or "Phiz." It must be remembered that not one of these plates, as originally issued, bore any title; and further, that the 8th, 9 th, Ioth, and IIth plates in Numbers 3 and 4 are said to bear Browne's first sobriquet, "Nemo," which he then used for the last time. The two Buss plates are, like the rest, destitute of any lettering. If they are printed off on buffcoloured paper they are probably spurious, though there are facsimile reprints on white paper as well, and great care must be taken with regard to these. One peculiarity about the first limited issue is that the name "Weller" on the signboard of "The Marquis Granby," which appears as a vignette on the title, is spelt "Veller," the $\mathrm{W}$ being substituted for the $\mathrm{V}$ in all subsequent issues. It should also be pointed out that in some copies of the original edition each plate has its appropriate inscription at the foot, that Browne's sobriquet "Phiz" takes the place of that of "Nemo," and that the plates in one copy may vary from the corresponding plates in another; all are genuine. These distinctions arise by reason of alterations 


\section{Rare Books}

made in the plates by the artist as the publication proceeded; and as issue followed issue in rapid succession, each was marked by some characteristic of its own. All may be genuine, but it is only the earlier issues that excite great competition, and only the very earliest that sell for large sums of money. An ideal copy may realise about $£ 30$, good copies $£ 6$ or $£ 7$, and ordinary copies $£ 3$, or even less. We have condensed the foregoing facts from Mr. Slater's excellent work on "Early Editions," as showing how important it is to fully understand the many minutiæ which go to make up an ideal first edition, which, however, as with other things, may sometimes experience a considerable "fall." For example, the copy which sold in the late F. A. Marshall's library in 1890 for $£ 31,5$ s. only fetched $£ 21$, ros. when it again came into the market in 1893 . The remarkable fact about ordinary first editions of Dickens and Thackeray, as well as Charles Lever, Ainsworth, and all the others of contemporary note, is their extreme commonness; there is nothing rare about them, for probably fifty examples of every one could be purchased in London within a day's walk. There are a few exceptions, but these exceptions are not of great critical or other value. They are exceedingly rare, and perhaps that is about as much as can 
be urged in their favour. Nevertheless, they are absolutely indispensable where a collector desires to have a complete series of the works written by the author or authors to whom he devotes his attention. Some months ago, for example, a copy of Thackeray's Flore et Zephyr, 1836, realised $£ 90$ at public auction; true, it was a fine copy, but that was the only intrinsic or other merit which could be claimed. Another unconsideredi trifle of little literary importance of Thackeray's which fetches large sums when it occurs in the market is "The Second Funeral of Napoleon," I 84I, a trifle which Mr. Michael Angelo Titmarsh, in the quiet seclusion of the shades, would be surprised to hear realises over twenty guineas.

With "Vanity Fair," as with some other celebrated books, there are what may be described as two first editions, but the valuable one is that with the woodcut of the Marquis of Steyne, which was suppressed after the issue of only a few copies; one, when accompanied by the original wrappers and advertisements, fetches about $£ \mathrm{I} 6$, or about ten times as much as an ordinary first edition, for which amount a splendidly bound édition de luxe copy of Thackeray's works in 26 volumes, with 1500 wood engravings, 270 steel engravings, and 88 coloured illustrations, can be obtained by those who want it. 


\section{Rare Books}

Naturally, copies which bear traces of having belonged to their particular authors, or other distinguished previous possessors, do not come within the category of ordinary examples. For example, a first edition of Thackeray's "Virginians," I 858-59, in the original parts as issued, realises from a guinea to $£_{2}$, according to condition; in April I 89 I an uncut copy in the original boards sold at Sotheby's for $£ 30$, simply from the fact that it contained the following " poetical " inscription in the handwriting of the author:-

"In the U. States and in the Queen's dominions

All people have a right to their opinions,

And many people don't much relish 'The Virginians.'

Peruse my book, dear R., and if you find it

A little to your taste, I hope you'll bind it.

Peter Rackham, Esqre., with best regards of the author." To the lasting joy of the collector, and to the extreme profit of the vendor, "dear R." did not bind it.

Both Dickens and Thackeray have suffered considerably at the hands of the too zealous persons who feed their own vanity by hanging on to the coat-tails of eminent men and claim the title of public benefactors by " resurrecting" from a well-merited obscurity some worthless tract or obsolete and ephemeral magazine article, and trumpeting it about as a masterpiece. An author is not perhaps the best judge of his own works. Milton, for example, had a much higher estimation 


\section{and their Prices}

of "Paradise Regained" than of "Paradise Lost," an opinion which probably no other man has entertained. But an author's desire that certain unimportant writings of his early days should be left in the limbo of forgotten things ought to be respected. The tendency of the day is not in this pious direction.

If there is one name in English literature more beloved and revered than another, it is Charles Lamb, and few will be disposed to quarrel with the collector for attempting to obtain a series of first editions of this immortal essayist. But Lamb published much which he himself was contented to let die a very natural early death, and which scarcely possesses a single feature of literary merit. It is a curious freak of collectors' " cussedness" that the least worthy memorials of the gentle Elia should also possess the highest commercial value. It is true that they are for the most part excessively rare, but rarity does not necessarily carry with it a corresponding intellectual value. His "Poetry for Children," I 809 , is a case in point. It is believed that there are only about a dozen copies of this little collection in existence, but that number more than satisfies the world's needs: two or three years ago one man in five millions was found willing to pay $£ 35$ for an example. For some time it was thought that this collection had quite faded out of 


\section{Rare Books}

existence, but by a succession of chances copy after copy came to light. The exhumation of this kind of treasure trove always brings in its train a crowd of other booklets and pamphlets, whose claims to a new lease of life are based entirely on the bookseller's not disinterested assumption that they were probably written by Lamb or some such celebrity. A composition entitled "The Butterfly's Ball and the Grasshopper's Feast" has frequently been catalogued as by Lamb, and, of course, priced accordingly, whilst its illustrations have been boldly assigned to Blake: both statements being entirely false, and without any kind of justification. First editions of Lamb were not popular when those of Dickens and Thackeray were in full demand, and the one has gone up pretty much in the same ratio as the others have declined. As an example, Lamb's "Tales from Shakespeare," I 807, with plates by Blake and Mulready, has increased in value from $f$ ro in 1888 to $\delta 25$ in 1892 . About 1870 the price for a fine copy was 7s. $6 \mathrm{~d}$.

So soon as the mania for one particular class of book declines, another springs into existence; for the market, naturally, must not be supposed to languish. A few years ago Shelley was made the stalking-horse, and grew all the rage. Nearly all his pub36 


\section{and their Prices}

lications were issued in extremely limited numbers, Byron publishing perhaps a thousand copies of his works to Shelley's score. Shelley's first editions will always be rare, although of course their value is governed entirely by the demand for them. The value of Byron's has advanced just as that of Shelley's has declined. One of Shelley's publications, "Laon and Cythna," I818, which a few years ago would readily sell for about $£ 7$ or $£ 8$, now realises only about three guineas. It makes all the difference, however, whether the copy possesses the leaf containing a Greek quotation from Pindar or not; of this it is believed there are fewer than six copies in existence, for one of which $£$ I 6 was paid in 1888 . In 1889 a copy of the first edition of "Alastor," 1816 , sold for fifteen guineas, but in November I893 a slightly inferior example (both were in the original boards) went for eight. A distinct rarity, such as "A Refutation of Deism," I 8 I 4, of which only about three copies are known, and of which one example last year fetched $£ 33$, scarcely comes within the range of comparison. The same may be said of several publications of Byron, such as, for example, the first edition of "The Curse of Minerva," I8I2, and of "The Waltz: an Apostrophic Hymn" [by Horace Hornem, Esq.], I8I3, which, both uncut and in origi- 


\section{Rare Books}

nal boards, sold in June 1892 for $£$ roo and $£ 86$ respectively, we grieve to relate, receded to $£ 30$ in I 894. Byron's "Poems on Various Occasions," I 807 , rose in value from $£ 20$ in

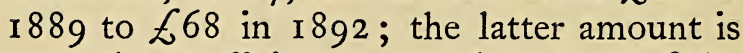
more than sufficient to purchase a set of the first editions of Robert Browning, with the exception of "Pauline," which is worth $£ \mathrm{roo}$, and a few other unimportant trifles.

Sir Walter Scott's works, like most of Byron's, were published in such large numbers - that few are ever likely to become rare; but they are rapidly rising in favour, if auction prices are any criterion. Six years ago a few pounds would have purchased a complete set of Scott's novels in the pristine beauty of original boards and uncut edges. Now, a first edition of "Ivanhoe," I 820 , fetches $£ 7$, a similar example of "Rob Roy," $\notin 6$, each in the three-volume form. Even within the last few years the collectors of first editions of Scott have multiplied by an hundredfold, with the very natural effect on the market. Examples bound in half-calf, or indeed in any other fashion, except the old state in which they were first sent out, are at a discount, and realise considerably less than the cost of their decadent dress. Even those copies which are in greatly dilapidated boards sell at fancy prices.

A few of the earliest editions of Tennyson 


\section{and their Prices}

and Robert Browning fetch high prices, especially the celebrated "Poems by Two Brothers." A facsimile reprint comes pretty much in the same category as an "antique" article manufactured in Germany; but such a contingency in the case of many excessively rare and expensive books is not without its intellectual value. Students are not, as a rule, men who can compete with the collector, and a reprint is as useful for study as the original. It is curious to note, in connection with this volume, an illustration of the extremes to which collectors go. Three copies of this little book were in the saleroom in 1893 . Two were ordinarily good copies. One being nicely bound in half-calf, realised $f_{7}$; but the other being in the original boards, with a paper label at the back, as issued in 1827 , ran up to $£ 28$ ! A large-paper copy sold for $£ 30$. For "Timbuctoo," the poem which obtained the Chancellor's medal at Cambridge, I 829, and which Tennyson himself considered (and rightly) as unworthy a place among his best poems, the enthusiastic collector has been willing to pay $\notin 5$. The person who confines his attention to first editions is, it must be admitted, not so extreme a case as the man who collects every edition of certain authors. This class of collectors are noble patrons of the booksellers. At Sotheby's, 


\section{Rare Books}

in May 1892 an almost complete collection of the works of Tennyson and Tennysoniana, comprising the first and nearly all subsequent editions, for the most part in the original covers and uncut, was on sale. The lot comprised 143 volumes, and the total of $£ 83$ gave an average of rather more than I Is. per volume. But if the three or four items which usually realise fancy prices were taken away, the average would show an awful loss on the original outlay, even at discount prices. There would be method in this madness if each edition differed from one another; but they did not.

Browning societies have unquestionably fostered the demand for first editions of the poems. A complete set (with one exception) of twenty-nine volumes of first editions of Browning's principal works, uncut copies and in the original bindings, realised in 1892 the very respectable total of $£ 33$, Ios. In the case of a few of Browning's publications, such as "Bells and Pomegranates," it makes all the difference whether they are or are not bound in parts as issued, the work named costing about five guineas when bound in morocco, but when unbound, and in original paper covers, its value is just trebled. To the lay mind a tastefully bound volume offers attractions not possessed by a set of parts in their dingy 


\section{and their Prices}

wrappers, but with a "collector" it is different. "Sordello" in a luxurious clothing of the best morocco is much less valuable than one in the original cloth and with a paper label. A set of the latest complete edition of Browning's works, substantially bound, in all sixteen volumes, costs less than a single copy of "Bells and Pomegranates" in the original parts.

The decline in the call for first editions does not imply that Ruskin is less read than formerly; each new edition of works of this great stylist finds a fresh stratum of readers, and the demand seems to increase with the supply. Five or six years since a copy of the first edition of "Stones of Venice" would not have been reckoned costly at $£$ I 8 in the auction room. In November 1892, at Sotheby's, a copy went for $£ 6$, i 7s. $6 \mathrm{~d}$. Certainly the last copy was a poor one, but a good example of this issue is procurable at about $€ \mathrm{IO}$. "Modern Painters" has gone down, even when each of the five-volume set of this epoch-making book is of the first impression. In November 1892 , ten volumes of his separate works (first editions), in the original cloth, realised just over three guineas. The publications of Mr. Ruskin which more than maintain their commercial value are those which are quite unknown except to the specialist. They are little pamphlets 


\section{Rare Books}

and tracts, which were, for the most part, printed in exceedingly small numbers, and are now practically unprocurable. Although there are about a dozen collectors who have spared neither time nor money to render their Ruskiniana complete, we believe that not more than one can claim to have an absolutely final series of the works of the " master." A rough calculation places the value of a complete set of Ruskin at not much short of $£ 300$ for about sixty distinct publications.

The apotheosis of a dead or a truly great living writer has many points in its favour, although, as we have seen, it is capable of being carried to an extreme. But it is quite a different thing when the "prospecting" bookseller exploits every ephemeral tract by living authors who have either not the power or the inclination to throttle this kind of unholy trading on the names of reputable persons. Both Mr. Andrew Lang and the late Richard Jefferies (to bracket together two names very different in permanent value) come in this category. It is, of course, one of the many severe penalties which overtake a person who has the misfortune to acquire fame during his lifetime -it is equally, of course, certain that the "celebrated" author does not participate one jot in the cash result of the wicked book- 
seller's artful manipulations. A local firm of booksellers makes a parade of no fewer than forty first editions of Mr. Lang's publications, which are offered at a total sum of nearly $£ 30$. With one or two exceptions these books are still in print, and by those so disposed may be had new for considerably less than half that amount. Some of these first editions are also the last; and the idea of asking $3 \mathrm{~s}$. $6 \mathrm{~d}$. for pamphlets which have ceased to possess any kind of interest, and which were originally issued nominally at a shilling, is certainly not one that appeals to every book-lover with equal force. The first edition of "The Library" is priced at $7 \mathrm{~s}$. $6 \mathrm{~d}$., or about double its original price, and the publication of a new, improved, and cheaper edition renders the previous issue quite obsolete, except with collectors, to whom it is a case of first edition or none. Many of Mr. Lang's editions, particularly the unillustrated volumes, are printed on "large paper"-it is difficult to imagine why. We get "Lost Leaders" on large paper, and we now expect some enterprising author to issue a volume of "Undiscovered Paragraphs" in the same form. What, it may be asked, is the raison d'être of a large-paper copy of a book? It should be an édition de luxe, not only printed with greater care on 


\section{Rare Books}

superior paper, but should possess a fair amount of extra illustrations, and bound in a sumptuous manner. And yet in how few books do we see even the faintest attempt at a fair quid pro quo for the much enhanced price demanded for these large-paper copies, which, in the majority of cases, are ugly in shape, cumbersome to handle, and show a lamentable waste of good paper.

The catalogue to which reference was just made also contains a set of the really interesting labours of Richard Jefferies : twenty-nine volumes in the original bindings are modestly priced at $£ 35$, which averages rather more than $\notin \mathrm{I}, 4 \mathrm{~s}$. per volume. In this collection is included "Jack Brass, Emperor of England," and "Reporting, Editing, and Authorship." The "Gamekeeper at Home" is a charming work, and by far the best of the long list. It will stand all the tests of the varying fashions of book-collecting; but the fact that it only realises about $30 \mathrm{O}$. in its original state is a proof that it is not rare; and the generally good condition of the copies which occur in the market prove that it has not been subjected to the hard reading which literally wore out the novels of Dickens and Scott.

The scarcest of all his books is a little brochure in paper covers, entitled "Suez- 


\section{and their Prices}

cide." This tract, rather absurd and entirely worthless, was originally issued at threepence. It now realises from two to three guineas, or even more, and is so rare that only a few privileged individuals have ever even seen it. An enterprising person-in this instance a "lady," who wrote from a Continental address -conceived the brilliant idea of manufacturing counterfeit copies. These were offered to confiding booksellers at about $£ \mathrm{I}$ each, at which price they went off with great rapidity.

Among living authors, it may be doubted if any are destined to hold so long and honourable a place with future generations as George Meredith and Thomas Hardy. The first editions of both are objects of the keenest competition. Mr. George Meredith's first book, "Poems," was issued in I 851 , and is now worth from ten to twelve guineas. "The Ordeal of Richard Feverel," by many regarded-and rightly so to our way of thinking - as one of the greatest novels which have appeared since the death of Sir Walter Scott, is much sought after by collectors, and three guineas would not be an extravagant price to pay for it. "Richard Feverel" did not by any means take the town by storm when it was first issued in I 859 -indeed, a second edition was not called for until nineteen years after; and when copies do turn up, they are usually in first- 
class condition. With Thomas Hardy's "Far from the Madding Crowd" it was very different, and collectors have to content themselves with exceedingly shabby examples of this truly great work, now worth a $£ 5$ note. We notice a paragraph in an American paper to the effect that a copy of the first edition of Mr. Hardy's “Tess of the D'Urbervilles" brought "ten times its catalogue price at a recent English sale," but the statement is not correct: it is certainly worth more than the original published price, which is a great achievement for a three-volume novel in the course of a year or two.

Another phase of the passion for collecting is suggested by the question which was asked in a newspaper some four or more years ago - "By which of his books will Professor Tyndall be best remembered hereafter?" If the present worth of them in money be any test, by his "Alpines." These command extraordinarily high prices-his "Hours of Exercise in the Alps" often fetching as much as $£_{2}$, IOs., and his "Glaciers of the Alps" \&3. Of the rarity of the former book no better illustration can be given than the fact that until the other day the author himself was not able to procure a copy. "I am told by a friend," he wrote to a bookseller who makes a speciality of "Alpines," "that you have two copies of my book. The price is 


\section{and their Prices}

high, and this is in a way very gratifying to the author. And as, unfortunately, I have no copy myself, I shall be glad if you will send the books to me at the price named." A very large number of book-collectors of unexceptionable taste have steeled themselves against the current passion for the first editions of unillustrated books, and have extended their operations, so to speak, to works on which the talent of the artist has been employed. There is much to be said in favour of this side of the subject, for the chances are a thousand to one in favour of the earliest edition against the second and all subsequent ones. The impressions or illustrations do not improve the oftener they are worked off. Books illustrated by Walter Crane, Hugh Thomson, and a few other of the most modern artists, show a distinct and unmistakable upward tendency, and those who love not merely first editions, but also beautiful books, will be wise to avail themselves of opportunities which are not rare at the present moment, but which may at any time become almost past praying for.

The "limited edition" is the most recent development of the first edition mania. One of the most notable examples in this category was Mr. R. L. Stevenson's onslaught upon the Nonconformist minister who wrote hard things of Father Damien. The attack ap- 


\section{Rare Books}

peared in The Scots Observer, and a privately printed edition of fifty copies was struck off; only nine were said to be offered for sale in London, at three guineas each-whether they were sold or not, the present writer is not in a position to state. The craze received another impetus when the works of $\mathrm{Mr}$. Norman Gale were put into the hands of the horn-blower. Mr. Gale's books of rhymes began to appear in I 885 , and at the present time a complete set of the first edition of his booklets, about twenty volumes on large and small paper, was first catalogued at $£$ roothe published price of many of which did not exceed 3s. 6 d. - then it dropped to 50 guineas, and it was even rumoured that a set might be obtained for less than that. Finally, a set which had been catalogued by a well-known firm of booksellers at about $£ 90$ came into the market-ostensibly as the property of a gentleman who had given up collecting-and this precious assortment of winged puerilities sold for 2I guineas! And so that little bubble has burst! There are probably people who believe that Mr. Gale's dainty jingle is going to live, just as John Dennis's friends argued that that renowned critic was a much greater dramatist than Dryden, and a more elegant poet than Pope. But it must be patent to every person of common sense that the mania for collecting this kind of pretty 48 


\section{and their Prices}

vanity is not one likely to last long. Some sort of comparison might be set up-but only in regard to their first-edition affinitybetween Mr. Gale's publications and those of the late J. K. Stephen; but there is a vitality in J. K. S.'s smart verse to which Mr. Gale's bundle of reeds cannot lay claim. The first editions of the former have a very distinct literary as well as commercial value, since in the later issues many of the poems have been considerably altered and, as some think, not improved.

Who, it may be asked, buys the books of which only one or two hundred copies are struck off? As a matter of fact, very many of these publications never get into the hands of the general public at all. Before these books are published, they are, after consultation held with the worshipful Guild of LogRollers, to which the writer probably belongs, and a circular setting forth in very indifferent English, but in not too modest terms, the merits of the enterprise, subscribed for by the booksellers, who, learning that the number to be printed is limited, buy up in the anticipation of a rise. While the movement is in its youth, its success is not despicable; private persons are freely canvassed, and not seldom drawn into the net (for it is that-nay, it is usually a fraud); even the trade subscriber, a pretty innocent, ere 


\section{Rare Books}

now has repented the act. A book is not going to sell or survive simply because its excuse for existence lies entirely in its paper, illustrations, binding, and printing, particularly when these items have nothing but a foolish idiosyncrasy, or a grossness which is too feebly suggested, to recommend them. A book, even if it consist of nothing but blank leaves, bound by artists such as Eve or Roger Payne, has a well-defined claim upon our consideration, for, being the work of a true artist, it cannot well fail to be artistic. But it seems to exact from us more than is strictly fair when we have indulgently passed the covers as quaint, and the interior of a volume turns out to be the theatre of a contest between the author and the artist for superiority in silly indecency or preposterous abortion. 
Pictures

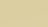





\section{Pictures}

If book-collecting is susceptible of being classed among forms of speculation, how much more so is the business of acquiring a gallery of paintings! It is positive gambling. The old school of buyer has pretty well died out, and the new one presents to our view, instead of men of family and fortune purchasing pictures on their own judgment, or that of sound critics or private friends, commercial men purchasing them from commercial men, sections of whom form a strange union of dealer, auctioneer, commission-agent, and adviser (in the strictest confidence). A Johannes Factotum; a new Proteus; a modern mercantile quadrilateral! "When broker meets broker, then comes the tug of war." This is an unquestionable fact, and it is a very important one, because it provides a key to the capricious and violent fluctuations which this description of property undergoes from season to season. This very remarkable change has been effected within the last half century. 


\section{Pictures}

The majority of private picture-collectors of the present day have gained money by industries with which they are familiar, and generously place a proportion of their earnings at the disposal of an expert, who, as we have already suggested, may bear towards the articles sold to his patron more than one sort of relationship, for investment in commodities of which they know next to nothing. Whatever changes occur in quotations, the auctioneer et catera stands to win -more or less; and he turns over on the same object half-a-dozen times very possibly during his distinguished career. The finest judges of paintings - such men as Ottley, Waagen, Hazlitt, Robinson-have not usually been buyers-not, at all events, on their own account. It is the middleman here, as elsewhere, who pulls the strings, and the same individual is ever playing many parts. It is a curious game, this merchandise in the higher efforts of genius, and a lucrative. The old or modern master has become, under latter-day auspices, as reliable an asset as the upshot of a pair of dice or a teetotum. The small dealer is a poor creature by comparison; he gets his material goodness knows where, and sells it he only knows to whom; but there is so little money in it, after all! You must have a big name to conjure with if you desire big prices, and that is not so readily 


\section{Pictures}

accomplished. Some of us, who are mere bystanders, think that we sometimes see such a thing as a proneness on the part of gentlemen to watch less jealously than was their wont their good repute. Well, it is altogether easier to run down-hill than to climb up. Facilis descensus, $\mathcal{E}^{\circ}$. These humble reflections appeared to arise naturally in our mind when we sought a clue to the at first sight startling vicissitudes attendant on the sale of pictures under the hammer.

Mr. George Redford, the venerable compiler of "Art Sales," regards the great Art Treasures Exhibition at Manchester in I 857 as having set the fashion in this respect, for he points out that, since that event, "there is scarcely a commercial man of position in Lancashire, Yorkshire, Derbyshire, and in Scotland, who has not his collection of pictures," whilst every town or provincial city has its picture-gallery and museum. Indeed, throughout Britain the ruling passion with the great majority of wealthy men has been directed in the way of art.

It is a notorious fact that pictures which a few years ago could scarcely be given away command to-day very high figures. It is difficult to convince ourselves that the pictures have not altered, and that the only change which time has effected is in ourselves. $A$ beautiful picture is, all things being equal, 
always a beautiful picture. But the unfortunate part of the matter is that for one who looks at a work of art for its own sake with a share of critical insight, there are ten who do so because they are advised that it is the right thing, and will roll up money against re-sale, which sometimes it does, and sometimes does not. It depends a good deal, this does, on the pleasure and convenience of the $\log$-rollers and teetotum-spinners.

However careful and exhaustive an inquiry may be made into the picture-sales and picture-fashions of the past and present, these sales and fashions afford a very uncertain indication of what may be the favourite pictures of the next generation. Taste varies in a more or less accentuated degree; and however much one may feel disposed to quarrel with some of the extremes into which we are led by those who are behind the scenes, there is no denying the perpetual fluctuation. Picture-collecting resolves itself not so much into a question of to buy or not to buy, as in the character of the collector's judgment and the depth of his pocket.

The commercial prosperity of a civilised nation may, to no small extent, be gauged by the extent to which the purchase of what may be generically classed as objects of art is carried. It is impossible to make even a rough estimate of what has been paid during, 


\section{Pictures}

say, the past two years for articles which are luxuries, and not in any sense necessaries; but if any such rough calculation could be drawn up, the total would be doubtless enormous. Considering that the "turnover" of the most eminent firm of art-auctioneers in London, and perhaps in the world, sometimes averages nearly three-quarters of a million sterling annually, and that two days' sale alone shewed a total of over $£$ I00,000, the country might be taken to be in a less straitened condition than the pessimist would have us believe. But it is almost too trite a fact to be worth repeating that the whole of the competition in King Street for the higher classes of property is almost independent of the state of trade, and lies between half-a-dozen individuals or institutions, whose withdrawal or absence would reduce the figures at once to a more normal and more trustworthy standard.

The collection of pictures of the late David Price cost its owner about $£ 90,000$, and when sold at Christie's in April 1892 realised rather more than $£ 70,000$. Superficially, the two totals would indicate a net loss of $£ 20,000$, for, whilst some of the pictures realised considerably less than $\mathrm{Mr}$. Price paid for them originally, others fetched more. But it must be remembered as a setoff that Mr. Price (who was a bachelor) was 


\section{Pictures}

a collector for nearly forty years, and that, apart from his business in the City, he had no interest in the affairs of every-day life, except so far as they related to pictures and picture-buying. There are, of course, many people who would regard $£ 500$ a year as a rather heavy sum to spend on a hobby; but when we look at the many hobbies on which vastly larger sums are annually laid out, with very little benefit, abstract or otherwise, to the spender, we cannot help regarding the amount which Mr. Price paid for his pleasure as money very well spent. Considering the gratification with which $\mathrm{Mr}$. Price would shew his picture-gallery, and looking at the results of a happy life and a fine discriminating taste, the transaction is preeminently a satisfactory one. How many similar speculators in stocks and shares, in horse-racing, or any other hobby, could shew a better result after nearly forty years' continuance? The tendency of the day is to omit a fair consideration of intellectual profit, which surely ought to count for something when the balance has to be struck.

One reads a good deal of lucky purchasers in the way of pictures. It is said, for example, that a season or two ago a dirty picture described as an "old master" was sold at Christie's for seven guineas, which, of itself, is most probable. But this picture 


\section{Pictures}

is further said to have been re-sold for $£ 80$, again for $£ 700$, and, after being cleaned, it was discovered to be a fine Terberg, and was ultimately purchased for a Continental gallery for $£ 2000$. It is also said, and this time we believe on very good grounds, that a picture which went a-begging in the West of England for five shillings on more than one occasion, was discovered to be a genuine Guido, and worth at least $£ 2000$. For all such anecdotes there is perhaps some sort of foundation, but they can only be accepted with extreme caution. Christie's, of all places in the world, is the least likely spot at which a "fine Terberg" would be sold as an "old master" for seven guineas, although it is certain that Terbergs so called have been sold there for much lower amounts. Mr. Woods, the senior partner in the historic firm just mentioned, has perhaps a wider and more accurate knowledge of pictures than any living person, and his judgment is rarely known to err.

The pedigree of a picture is its most valuable extraneous or collateral recommendation. It governs its price when it comes up for sale under the hammer. There are so many forgeries, of all degrees of merit or want of it, and so many copies which possess the extremely inconvenient property of closely resembling the original. Where a picture 
can be traced without a break from the artist's easel down to the present day, there is of course no call for a doubt as to its genuineness. Unfortunately, this cannot always be done, particularly in the case of a prolific artist, more especially if he was obscure and unappreciated in his lifetime. This was the case with many men whose pictures now individually realise sums which to them would have been a fortune.

The Dutch school affords the widest possible scope for comparisons in the matter of past and present prices. Down to the first quarter of the present century, the finest works might be had in this country at sums which now appear absurd. Within the past half a century the values of these old Dutch masters have gone up with a bound, for we have at last come to regard absolute fidelity to nature as distinct qualities in the tout ensemble of a picture. To take, as a collective illustration, the famous collection of the late Adrian Hope, sold on June 30, I 894. It may be doubted whether these seventyfive pictures cost anything like $£$ I0,000. Mr. Hope ceased to collect between thirty and forty years ago, after having obtained all he wanted, at prices which seem absurdly small when compared with those of to-day, the total of the sale, in fact, being close on $£ 50,000$. It was expected that the amount 60 


\section{Pictures}

would have been nearer $\delta \mathrm{I} 00,000$, but many of the pictures had the appearance of having been "touched up." All things considered, the collection sold extremely well.

To particularise a few of the more striking examples sold during the last few seasons, the splendid work of Jan Both, "Abraham with Hagar and Ishmael," in which the sunshine is manipulated in a manner at once extraordinary and unique, sold in 1828 for rather less than 300 guineas, ran up in 1875 to 4500 guineas, and unaccountably fell to the less artificial price of rogo guineas when sold with the Mildmay collection in June I893, a fall almost without a recent parallel so far as regards Dutch pictures. So, too, Both's hilly and well-wooded landscape, which realised $£ 175^{2}$, Ios. at the Bredel sale in 1875 , declined to $75^{\circ}$ guineas in the Dennistoun sale in June I894. Genuine examples of this master are rare; excellent copies by contemporary hands occur pretty frequently, and their market value is usually something like $\delta_{5}$ each. Slightly different, however, is the case of Both's Italian landscape known as "The Muleteer," which in 1846 went for 320 guineas, and in the Mildmay sale for 370 guineas. A really perfect Cuyp, a landscape in which his marvellous treatment of atmospheric effect is seen at its best, is a great rarity in the $6 \mathrm{I}$ 
market, and when it does occur, $\Varangle 2000$ is not considered an extravagant figure. The Dudley collection in I 892 contained one such, which was knocked down for I 800 guineas. Another example occurred in the Hope sale in 1860 ; this splendid work was sold for 550 guineas; it has now advanced to 2000 guineas. But one may obtain Cuyps, so called, sometimes at prices ranging from 20 to 200 guineas, signed and dated, but whether they are always genuine is another matter. The latter sum was paid in June I 892 for a sunny river scene which was at one time in the collection of the late Earl of Bessborough. What has been so aptly described as the "mellow clearness" of Nicholas Berghem does not seem an attractive attribute to picture-buyers; for the works of this artist scarcely ever approach four figures, and, as a matter of fact, exhibit a slight downward tendency. The faultless little example entitled "Cattle Passing a Ford," which realised at the dispersal of the Clewer Manor collection in 1876 $£$ I207, IOs., dropped to $£ 682$, Ios. when it was again sold with the late $\mathrm{Mr}$. Barclay Field's pictures in May I893. Another first-class example of this artist, "Milking the Goats," sold in I86I for 300 guineas, but with the Field collection it went for 240 guineas. In February 1893 an Italian 


\section{Pictures}

river scene realised 52 guineas, but a portrait of a man in a black dress and lace collar got no farther than four guineas. But Berghem had many scholars and not a few imitators; and although a prolific workman-for his wife kept him to the mark, it is said-many paintings are sold as his in which he could not possibly have had a hand. The pictures of one of Berghem's pupils, Pieter de Hooch (whose interiors are unrivalled in the magical manner in which the light is suffused throughout the several apartments), fetch very high prices, but this was not always the case. Of the two examples in the Mildmay collection, one, which recently fetched 2800 guineas, was sold in 1800 for $£ 37$, and the other, for which 700 guineas were paid, even in I $84 \mathrm{I}$, only realised $\delta \mathrm{I} 90$. On the other hand, the Interior by this artist in the Hope collection sold for 2 I 50 guineas, its price in $186 \mathrm{I}$ being $£ 44 \mathrm{I}$. As in the case of Berghem, and nearly every other artist of eminence, so with Memlinc; for every single work of the master there are at least a dozen pictures catalogued as his, but which bear a very faint, far-off resemblance to the real thing. Really genuine examples of this early Flemish painter-usually the Madonna and Child-fetch good prices. The beautiful picture, in perfect preservation, sold in June I 893 in Lord Revelstoke's 


\section{Pictures}

collection for I I 00 guineas, a considerable advance on the sum paid for it five years ago, namely, 750 guineas. Another picture of the same character, "Madonna and Child," has recently been sold for 885 guineas.

Hobbema's pictures may be taken as representing the maximum recently paid for the Dutch masters. The most important example of this artist which has ever come into the saleroom is "A View in Holland," sold with Lord Dudley's pictures in June I 892, when it realised 9600 guineas. Dr. Waagen has described this without exaggeration as "a picture which is equal to a whole gallery;" and further, "for striking truth of nature, delicacy of aërial perspective, effect of bright afternoon sun, and masterly lightness of execution, there are probably very few pictures in the world which bear a comparison to this." This picture was at one time in the collection of the Right Hon. Edward John Littleton, for whose ancestor it is said to have been expressly painted. It would be exceedingly interesting to know how much was originally paid for it. It was privately purchased from the first Lord Hatherton by the Earl of Dudley for 3000 guineas. Close to this comes the landscape with watermill which sold in the Secrétan collection in 1889 for 5200 guineas. In 1802 this picture was knocked down for 280 64 


\section{Pictures}

guineas, and in 1880 for $f 8800$. Each of these splendid pictures has the advantage of having the figures painted by Adrian van de Velde. In the Dudley collection there were two others by Hobbema, one of which, a richly-wooded river scene, sold for 1900 guineas, a slight depreciation in its value since 1878 , when it fetched $£_{2205}$; the second, a landscape, half as large again as the last mentioned, realised 2300 guineas. A woody landscape in the Field collection sold in June I 893 for 4500 guineas. The well-known "View of a Lock," with the Herring Packer's Tower, is another illustration of the extreme difference between past and present prices. In the Van Alphen sale, I810, it sold for $£ 90$; in 1831 it had advanced to $\ell^{2} \mathrm{I} 3$, and two years later it reached 400 guineas, and in June 1893 it was knocked down for 2200 guineas, and even at that high figure it is exceedingly cheap.

The works of the two Ostades sold during the past few years differ very much both in quality and price. From Io to 2500 guineas seems a fairly long sliding-scale, and yet works by (or attributed to) Adrian van Ostade have been dispersed at both figures. The most notable of a long list is the "Interior of a Kitchen," with four peasants and a dog seated by a fire, a little canvas, measuring only $\mathrm{I}_{4}$ inches by $\mathrm{I} 3$ inches, which

$$
65 \quad \mathrm{E}
$$




\section{Pictures}

realised $\delta_{4} \mathrm{I} 00$ in the Schneider collection, I $86 \mathrm{I}$, and was sold with the Dudley pictures for $\AA_{2625}$. The Hamilton Palace example of the same artist's "Interior of a Cabaret," sold in I882 for $£$ I827, Ios., dropped to $£ 776$, Ios. in 1893. An historically interesting example of this master's works, which occurred in the sale-room in May I 893, still further illustrates the drop in the commercial value of Ostade's works. "The Hurdy-gurdy Player," which is signed, but which does not appear in Smith's Catalogue, was purchased in Paris by the exEmpress Eugénie for about $£ \mathrm{I} 300$, and by her it was presented to her landlord at Chislehurst, and is now appraised at $55^{\circ}$ guineas. An "Interior," which in I885 was sold for 900 guineas, fell during the past season to 730 guineas; whilst "Boors Playing at Tric-Trac" sold in May I 893 for $65^{\circ}$ guineas. Of the very few perfect examples of the less generally known Isaac Ostade, "The Cabaret," signed and dated I646, may be mentioned as having realised at the San Donato Palace sale, I880, $£ 2000$; in the Secrétan sale, I889, £ I 575; and with the Mildmay pictures, in June last, $£$ I 572. On the other hand, a woody landscape by this artist, selling in 1846 for 79 guineas, had advanced by June I 893 to 380 guineas.

Genuine Rembrandts fetch very high prices; 66 


\section{Pictures}

though any person may cover the walls of his house with by no means objectionable pictures, which certain dealers who sell them will assert to be Rembrandts, at something like an average of $\delta \mathrm{I}$ per square yard; and if one's friends were always so easily persuaded as oneself in these matters, no doubt Rembrandt-walls would be largely on the increase, for the supply is never likely to fall short of the demand.

The most remarkable examples of this master which have come under the hammer within recent years were among the pictures which formed the collection of the late Lord Dover at Whitehall, and sold with Viscount Clifden's property in May I 893. These were portraits of the Burgomaster Six and his wife, for many years in the possession of a descendant (who settled in the north of Holland) of this couple; the pair realised together I 2,200 guineas, and they unquestionably take very high rank in the series of matchless portraits which this artist painted. Realistic in every sense also is the portrait of Hendrikje Stoffels rising up in bed, and in the act of putting back the curtains with her hands, and looking with fixed attention at some object in the room. This picture, which is fairly well known through Cooper's mezzotint engraving, is absolutely perfect in its illusionary effect on the spectator. It sold 
for 5000 guineas in the Wertheimer sale in I892. In neither of the foregoing instances have we any means of indicating the prices at which they previously changed hands. The Dudley picture of "St. John Preaching in the Wilderness" shows a slight depreciation in value, for in 1845 it realised $\measuredangle 3000$; in 1892 it sold for $£ 2625$. The brilliant portrait of "A Young Lady" shows a reverse state of things, for a few years ago it sold for $£ 1690$, and in June 1893 , with the Mildmay pictures, for $£ 2667$. So, too, the portrait of Nicholas Ruts, which sold in the collection of King William II. of Holland for $£ 283$, realised in the Hope sale in June I 894 the high figure of 4700 guineas.

The pictures by Ruysdael, which were at their lowest ebb at the beginning, and at their highest during the "fifties" of the present century, have now reached a middle line. One of the most attractive examples of this artist, as well as of a size which one rarely meets with at an auction nowadays, "A View on the Shores of Scheveningen," sold at the dispersion of the Choiseul gallery in 1772 for $£ 68$. It passed into the possession of Prince de Conti, with whose pictures it was sold in 1779 for $£ 96$, which price included the equally superb companion picture. The pair were subsequently the property of the 


\section{Pictures}

Marquis de Marigny and of the Baron Verstolk von Soelen, and at the Mildmay sale in June 1893 the two fetched 4600 guineas. The equally famous and absolutely perfect picture known as "The Ruin," which has during the past century and a quarter formed one of the chief glories of at least half a dozen renowned collections, came under the hammer in 1875, but was appraised at only 1400 guineas in the Dudley sale. The very fine "Waterfall," which in I85I was appraised at 355 guineas, realised 1600 guineas in the Hope sale; when, also, a small picture of an old fort-which sold in 1857 for 126 guineas -was knocked down at the enhanced figure of 610 guineas. Those who cannot afford these large amounts may be comforted to learn that every season Ruysdaels are to be had from Io to 40 guineas, many of them signed. Examples about the authenticity of which there is no doubt may be had for 210 guineas, at which figure the charming little landscape exhibited at Burlington House in 1892 was sold with the Lawrence pictures in May of that year; whilst the admirable view of a river and a cascade in the Marquis of Exeter's collection realised $£ 250$ in I 888 . A river scene, a perfect example of Solomon Ruysdael's work, may be here mentioned as having doubled in value in about a quarter of a century : in I 876 it sold at Mr. Albert 


\section{Pictures}

Levy's collection for 400 guineas, in June I 893 it realised 870 guineas.

For some reason or other, into which it will not be necessary to enter here, Rubens does not seem to be a favourite with copyists, and first-class examples of his work do not occur at all frequently in the market. The only two recent exceptions of importance were portraits of his first and second wives. The former, Elizabeth Brandt, realised at the Hamilton Palace sale in $1882,175^{\circ}$ guineas, but it has now dropped to 650 guineas, a fate which, curiously enough, has attended nearly every picture from that famous collection which has since recurred for sale. The second portrait realised 60 guineas at the Wynn-Ellis collection, and then dropped to twenty. The most carefully painted and in many respects the finest Rubens which has been sold under the hammer for some years is the picture of "Juno Transferring the Eyes of Argus to the Tail of the Peacock." It measures 9 feet by 12 feet, and was formerly in the Durazzo Palace at Genoa; it went in 1893 for 1500 guineas, and would not have been dear at ten times that amount. The brilliant picture of a wild boar hunt may be regarded as one of the finest examples of Rubens sold during the past two seasons : it realised $£ \mathrm{I} 666$ at the King of Holland's sale in I850: at the Adrian 


\section{Pictures}

Hope sale it slightly advanced to I660 guineas.

The name of Teniers finds itself attached to an extraordinary assortment of pictures, good, bad, and indifferent. In 1892 three large canvases realised the magnificent total of just over 30 guineas. An "Interior," with three Boors seated round a table in front of a fire, with one of them in the act of lighting his pipe, exhibited at Burlington House in 1892, sold in May of that year for 23 guineas. The set of five copies by Teniers from Bellini, Paolo Veronese, Palma Giovanni, Guido Reni, and Titian, at one time in the Blenheim Palace collection, realised $£ 30$, 19s. 6d. in January last. "Signed" pictures of this master are common enough at five guineas each. The two really firstclass examples which occurred in the Dudley sale do not, however, come in this category. "Christ Crowned with Thorns," described as "a rich composition of great power of colouring," was knocked down for 700 guineas : forty-eight years ago it realised rooo guineas. The second example, the courtyard of a cottage, a small picture, fourteen inches by twenty-one inches, was sold for 470 guineas.

As illustrating the extreme sums paid for similar pictures by one artist, it may be mentioned that the Duke of Hamilton's 
example of J. van Huysman's vase of flowers sold for $£ 1228$, whereas numerous other examples, some of them signed, have changed hands at 37 guineas, and even less. A charming picture of a group of roses, peonies, and pinks in a terra-cotta jar on a marble slab realised 175 guineas in the Bagot sale, 1836 ; 500 guineas at the Earl of Clare's sale, I 864 , and 460 guineas at the Barclay Field sale in i 893 .

The pictures of the Van de Veldes, Adrian and William, and of Jan Wynants indicate very little disposition to run to either of the two extremes; and in proof of this two instances may be quoted from the Mildmay sale. A. Van de Velde's pastoral scene known as "The Bagpiper" sold in I 829 for 300 guineas; it is now appraised at 500 guineas. J. Wynant's "Highwaymen attacking Travellers" (with the figures by Wouverman) realised 185 guineas in 1835 and 410 guineas in 1893. Both were at one time in the possession of Baron Verstolk van Soelen, and each is described in Smith's Catalogue Raisonne. Good examples of each artist always fetch fair prices, from 200 to 400 guineas. Of Wouverman's works, first-class examples almost invariably run well into four figures. The clever picture depicting the halt of a shooting party was knocked down at the Dudley sale for 3500 guineas. The 


\section{Pictures}

numerous examples of this artist which have recently occurred for sale indicate a steady rise, in several instances doubling in value in a few years. One of the most remarkable illustrations of the increased popularity of pictures by old Dutch masters occurred at the Hope sale, Gerard Dow's famous little panel "The Flute-Player" realising 3500 guineas -less than half a century ago it was knocked down for $£ 320$.

The collection of the late Right Hon. George, last Earl of Egremont, sold in November 1892 , may be quoted as a fair sample of the treasures sometimes described as "old masters." With $£$ roo in his pocket, the not too particular aspirant to the possession of an art gallery might on the occasion in question have furnished himself with an almost complete Italian series. There were here, for example, a couple of Borgognes for a guinea, a Canaletto for $2 \frac{1}{2}$ guineas, a pair of Caravaggios for 4 guineas, a Correggio (admittedly "after" in this case) for IOs., a pair of Domenichinos for 4 guineas, Guidos for even less, Tintorettos from 25s. each, and Paolo Veronese from $£_{2}$, I 5 s. Certain subjects, such as Canaletto's "View of the Grand Canal, Venice," Guido's "Madonna," Giorgione's "Woman taken in Adultery," and many other pictures which are instinc- 
tively associated with certain painters, crop up in the saleroom with a frequency which would lead one to believe that, if the respective artists lived and worked for three average lifetimes, they could scarcely have executed all the pictures by which they are most often represented at auctions. The two Canalettos in the Dudley sale, "A View in Venice," and "A View on the Grand Canal," are the parents of a very large illegitimate offspring. The former of the two above mentioned sold in 1873 for $£ 3360$, but dropped in 1892 to $£_{2055}$; whilst the second, selling at the dispersal of the Stowe collection in 1848 for 105 guineas, ran up in 1892 to 2100 guineas. Another view of the Grand Canal with the Dogana and the Church of Sta. Maria della Solenta, at one time in the collection of the late Mrs. Danby Harcourt, Swinton Park, sold in 1892 for 600 guineas; and a view of Venice, painted between 1747 and $175^{\circ}$ for the owner of Holland House, realised in May 1893520 guineas. Every private and public gallery, from Dresden to London, has its "View of Venice" and the "Grand Canal," and, considering the price at which they may sometimes be had, there can be no excuse for their absence.

First-class examples of Botticelli occur with considerable frequency in the auction- 


\section{Pictures}

room, but, except when in the very finest condition, the tendency is decidedly downwards. This artist's eternal Madonna and Child varies very much in condition, in style, and in price. One of the very best examples which has ever appeared in an auction-room occurred in the Leyland sale in May I892, when it realised 1250 guineas. It is described both by Dr. Waagen and by Messrs. Crowe and Cavalcaselle, and is a panel measuring 35 inches by 28 inches. A slightly smaller example-which cost its owner 300 guineas - of the same subject was sold at the same time for 100 guineas, and yet another, still smaller, measuring $23 \frac{1}{2}$ inches by $15 \frac{1}{2}$ inches, went for 235 guineas. Two others of the same subject occurred in the Dudley sale, and realised 400 guineas and I 50 guineas respectively-the former sold for 500 guineas in 1854 . We have heard it stated that a genuine and perfect Correggio has never been sold at Christie's; and the prices paid for two alleged examples in the Dudley sale ( 155 and 85 guineas) would seem to bear out this statement. The pictures were in each instance of angels' heads, the canvas being 19 inches by 19 inches, and 20 inches by 28 inches respectively, and are described by Dr. Waagen as two fragments of the celebrated fresco, the Coronation of the Virgin, in the old apsis of 
San Giovanni at Parma, which the chapter removed in the last century for the purpose of enlarging the choir; and further, "they agree so entirely with the fragments of the picture of the Virgin crowned by Christ, preserved in the library at Parma, and also with the angels in the Assumption of the Virgin in the Cathedral at Parma, that no doubt of their originality can exist." Dr. Waagen is an authority whose ruling few will care to question, but his judgment in the present instance is probably at fault. Sir Charles Eastlake's example of this master sold in June 1894 for 720 guineas. Firstclass examples of Carlo Crivelli occur every season. One of the most important of recent years is the Dudley panel of "The Virgin and Child with Saints," measuring 75 inches by 77 inches, which was exhibited at Burlington House in $187 \mathrm{I}$, and again a few months before it was sold in 1892 ; it realised the respectable sum of 7000 guineas, but the average price for good pictures of this distinguished tempera painter is about 300 guineas, and fairly good copies may be picked up for as many shillings. Much less common is the authentic work of Carlo Dolci, one of the most successful of whose pictures is the "Head of the Virgin," in a blue drapery, which is best known through Cooper's engraving, 


\section{Pictures}

and which, selling in the Stowe collection in 1848 for 185 guineas, realised at the Dudley sale 375 guineas.

One of the most extraordinary "drops" of recent years occurred in connection with Giorgione's "Souper Venitien" (at one time in the collection of the Abbé Celotti of Florence, when it was known as "Un Festin Profane"): at the San Donato sale, I870, this picture sold for 2200 guineas, but at the Dudley sale it was knocked down for 210 guineas. Another considerable fall may be bracketed with the Dolci: Garofalo's "A Grecian Sacrifice" realised I 400 guineas in 1867 , but in 1892 its selling value had receded to 380 guineas. From a strictly commercial point of view these may be regarded as Lord Dudley's worst bargains. On the other hand, Filippino Lippi's portrait of La Simonetta, in crimson and white dress, which Vasar describes as "una giovane e bella donna di collo notabilmente lungo," and which will be remembered by the few remaining intimates of the poet Rogers; in 1856 it sold for 185 guineas, in 1863 for 460 guineas, but in 1892 it ran up to I 600 guineas. A very much greater advance was experienced in the case of Raphael's famous "Crucifixion." This work is a panel inscribed "Raphael Vrbinus P.," and was painted for the Chapel of the Gavin or 


\section{Pictures}

Gavari family in the Dominican Church at Castello about the year I500, where it remained for nearly three hundred years. It was acquired by a Frenchman who gave 4000 scudi for it, in addition to a very bad copy, which to the present day occupies the place of the original. It was afterwards purchased by the Prince de Canino for Io, 000 scudi at the sale of Cardinal Fesch. It became Lord Dudley's property for probably not more than 2000 guineas, and at his sale it realised 10,600 guineas. It is an ambitious picture, measuring 102 inches by 65 inches, and is remarkable as having been painted by the master before his seventeenth year. An equally famous picture of the same artist, "La Vierge à la Légende," or "La Vierge de Novar," said to have belonged to Charles the First, and formerly in the collection of Lord Gwydir (when it was ascribed to Giulio Romano), shows a slight advance from 3000 guineas in 1878 to 3050 guineas in 1892 . It has been engraved by Forster, and measures $3 I^{\frac{1}{2}}$ inches by $23 \frac{1}{2}$ inches. Titian's "Ariadne in Naxos" realised in the Walsh Porter sale in $1810 £ 1575$; it March 1894 it was knocked down for $£ \mathrm{I} 05$. These prices, of course, represent the amounts paid for the very finest original examples of the great Italian artist. The works of Salvator Rosa 


\section{Pictures}

and Andrea del Sarto appear to decline in value if not in interest. The brilliant picture in the Dudley collection by the firstnamed painter of the finding of Moses, a companion to the justly admired example in our own National Gallery, was at one time in the Colonna Palace; it was brought to England by W. Y. Ottley, at whose sale in I 801 it realised 1050 guineas; the Duke of Buckingham bought it from the Orleans gallery for $£ 2500$, and at his sale in 1848 Lord Dudley paid 1000 guineas for it; in I 892 it only fetched 450 guineas. The "Pieta" of Andrea del Sarto sold in 1878 for 1700 guineas; in 1892 it realised 945 guineas. Tintorettos shew a considerable fluctuation. One of the most successful representations of his favourite subjects of Adam and Eve, formerly in the possession of the Orlandini family of Florence, sold at the San Donato sale in 1870 for 240 guineas, and at the Dudley sale for 6ro guineas. On the other hand, his portrait of a Venetian Admiral, which realised at the Hamilton Palace sale $£$ I I 55 , dropped to 860 guineas in 1893. The Tintorettos in the Leyland sale of 1893 realised from 50 guineas to I05 guineas, probably much less than half the price at which they were acquired by their late owner.

Pictures by modern English (or British) 
artists exhibit a constantly recurring fluctuation. This is more especially apt to happen when the unsold works of recently deceased artists are sold together. Take, for example, the batch of nearly three hundred pictures and drawings of the late John Constable, which were sold in two portions in November 1892 and June 1893 . Only in a very few instances were three figures reached, and, as a general rule, the amounts did not exceed twenty or thirty guineas each. Several realised from two to six guineas apiece, certainly not an extravagant price for the work of an R.A. On the other hand, among the pictures of $\mathrm{Mr}$. J. S. Hodgson sold in June 1893, a faultless picture by Constable, entitled "Hampstead Heath," painted in 1830 , and measuring 26 inches by 39 inches, sold for 2550 guineas. Perhaps the very finest example of this artist at his best which has been sold at auction is the scene on the river Stowe, sometimes called "Constable's White Horse," for many years the property of the late Richard Hemming, at whose sale in April 1894 it realised 6200 guineas; less than forty years ago it was purchased for 600 guineas. The "remaining works" of three well-known members of the Royal Institute of Painters in Water-Colours have come under the hammer during the last year or 80 


\section{Pictures}

two with unfavourable results. The average price of Charles James Lewis's works, among which were many fine examples exhibited at the Royal Academy, the Royal Institute, and elsewhere, was only about $£ 7$ each; some, indeed, going for three guineas per pair, and in only one instance were 32 guineas reached! The same may be said of the works of Thomas Collier, whilst those of Paul J. Naftel show an average of about $£_{4}$ each. With the exception of a few unfinished or hastily executed sketches, these pictures would not disfigure any gallery. As they are, for the most part, appropriately framed, it may be questioned if they realised actual out-of-pocket expenses. The sale of the remaining works of the late Vicat Cole, R.A., may be taken as the most recent illustration, not only of the change in picture fashions, but of the extraordinary depreciation which inevitably occurs when a large number of works by the same hand are thrown on the market. This collection comprised nearly 600 sketches and finished studies in oil and water-colours, and I 54 items realised a total of $£ 770$; the highest for a single picture being 30 guineas.

Much inferior work, which at one time was fashionable, and therefore costly, has experienced a fall which scarcely justifies the expectation of it ever rising again. This is $8 \mathrm{I}$ 


\section{Pictures}

especially the case with eminent R.A.s whose facility at turning out quantity is more conspicuous than their regard for quality. Wealthy collectors have (or had) a practice of purchasing direct from the artist, and this naturally precludes the possibility of setting up any sort of comparison between the prices originally paid and subsequently realised, as the purchasers are in most cases dead before the pictures are dispersed through the medium of the auction-room. To take as a collective example the watercolour drawings of the modern English and Continental schools, the property of Messrs. Murietta, and sold in January I894. In this collection nearly every modern painter of any eminence was represented, including Copley Fielding, Birket Foster, R. W. Macbeth, W. Collins, T. S. Cooper, David Cox, F. Goodall, Seymour Lucas, and foreign artists such as Pradillo, Mesdag, Madrazo, Jacquet, and Hernandez, but the 1282 lots only realised $£ 21,336$, or less than an average of $£ 20$ each. The exceedingly extensive and representative collection of pictures and water-colour drawings of the late Henry Wallis, of the French Gallery, sold in I 892-93, may be bracketed with those of the Muriettas from their not altogether dissimilar character, and the absurdly low figures at which some of the most successful 82 


\section{Pictures}

works of distinguished painters were knocked down. The average of the Wallis pictures was lower than that of the Murietta, but only slightly so.

There is a sustained and very healthy revival in the taste for the best pictures of the older English masters, and some of the prices paid within the last year or two are very remarkable when compared with previous results. This class of art has been much too severely neglected, and our own National Gallery is conspicuously weak in this respect. This feature in the history of picture sales is more remarkable than that which deals with the past and present prices of the best works of Sir Joshua Reynolds and his great rival, George Romney. Indeed, the pictures of these two great portrait painters may be regarded as having formed the sensation of the last two seasons. During the first quarter of a century after the death of both artists, some of their most successful examples realised at auction considerably less than $E 100$ each, and so far as Romney is concerned, $£ 20$ was regarded as an extravagant price to pay under the hammer. At the sale of the late Miss Romney's effects in May I 894, a portrait of Mrs. Tickell (Miss Linley) sold for I I 50 guineas. At the artist's sale in 1807 it was bought in for four guineas; a portrait of Mrs. Billington 
as St. Cecilia realised 900 guineas, its former price being eight and a half guineas; a portrait of Mrs. Inchbald, the authoress, 950 guineas, and of James Thomas Paine, 300 guineas.

The portrait of Mrs. Thornhill reached I 50 guineas in July I894. In the past season (I 895), three works by this artist realised a total of over $£ 5000$ at the James Price sale, or very nearly double the amount which Romney earned in one of his best years. When it is remembered that Romney rarely received as much as $£$ ioo even for a whole-length portrait, the high prices which have recently been paid for some of his pictures may well be advanced in proof of the theory that the best English masters are rapidly coming into favour.

The same remark applies with equal force to Sir Joshua Reynolds, whose portrait of Lady Betty Delmé (and children) sold in July I 894 for II,000 guineas, the highest price ever paid for a picture at auction in this country. On the same day, the portrait of the Hon. Mrs. Monckton sold for 7500 guineas, but it had been slightly varnished; in all other respects the two pictures were in the finest possible condition, and came direct from the families for whom they were specially painted. These are, of course, essentially "fancy" prices, which can only be expected 


\section{Pictures}

for the very finest pictures in perfect condition. As an instance of the greatly enhanced value of even moderately good examples of this master, it may be mentioned that the portrait of Mrs. Matthew, the patroness of art, painted in 1777 , which sold in 1876 for 900 guineas, realised 4400 guineas at the Duchess of Montrose's sale in I 894.

The sale season of 1895 will take rank, so far as Gainsborough is concerned, as perhaps the most remarkable in the commercial history of his pictures. One sale alone contained ten works attributed to him, but of which at least five were genuine examples of the very first class. The very finest specimen of this exquisite colourist was the perfect and beautiful portrait of Lady Mulgrave, an oval (29 inches by 24 inches), in white dress, black mantle, and hair poudré; it realised 10,000 guineas-thirteen years ago it changed hands for 1070 guineas! The celebrated portrait of the Duchess of Devonshire realised in 1876 the highest amount, IO, IOO guineas, ever paid for a Gainsborough, so that the "Lady Mulgrave," which is quite a small picture, comes in a good second. At the same sale, that of the late James Price, a three-quarter length portrait of Lady Clarges brought 2000 guineas; seventeen years ago it was sold for $35^{\circ}$ guineas!-and an excellent portrait 85 
of Viscount Mountmorres realised a similar amount; the renowned chef-d'ceuvre "Repose" only fetched I 400 guineas. The last-named work is an exceedingly beautiful landscape, as fine of its kind as anything offered for sale during the last two seasons - but the rage is for Gainsborough portraits of pretty women, and not for Gainsborough landscapes. At the Duchess of Montrose's sale in May I 895, this artist's three-quarter length of Madame Le Brun, in white dress trimmed with lace, sold for 2 I 50 guineas.

Equally remarkable illustrations of this upward tendency have also occurred in connection with David Cox. When it is remembered how difficult this artist found it to dispose of his pictures and drawings, the prices at which they are now eagerly acquired become all the more remarkable. Cox considered fifty guineas a very fair price for some of the most carefully executed of his works. It was at this figure that he sold "The Hayfield," which in 1875 realised $£ 295^{\circ}$ in the Quilter sale; whilst at the dispersion in I889 of another portion of the same collection, sixteen drawings came under the hammer at sums varying from 100 guineas to 2300 guineas. The three pictures, "Counting the Flock," "Driving Home the Flock," and "Collecting the Flock," realised in I 888 I 980 guineas, 


\section{Pictures}

I 300 guineas, and 2250 guineas respectively. The first-named, it may be mentioned, realised at the Levy sale in 18762300 guineas. One of the largest of this artist's works, "Collecting the Flocks, North-West France," sold in the Bullock collection, I 870 , for 400 guineas, but ran to $145^{\circ}$ guineas in June 1892 . A series of two dozen sketches by Cox occurred in the sale of the late Peter Allen's pictures in March I893, and the best of them went well into three figures, whilst the largest did not exceed 30 inches by 25 inches, and the majority were only about half that size. The matchless "Vale of Clwyd," which sold in the Murietta collection, 3oth April I 892, for 4500 guineas, marks the highwater mark of David Cox's works. The artist himself valued it at $£ 95$, and exchanged it with a Midland dealer, who sold it for $£ 70$. In 1860 it was knocked down for 265 guineas at the Briscoe sale; in 1868 it sold for $£_{480}$, and in 1872 for $£_{2000}$. Peter de Wint and Copley Fielding may, for several reasons, be considered in the same paragraph as David Cox.' More fortunate in his lifetime than Cox, De Wint sometimes received a fair value for his pictures and drawings, although they are not now nearly so much in request or realise such high prices. Two of the best which 
have been sold at auction in recent years are "Lancaster" and "Lincoln," in the Quilter sale of 1889 , realising $£$ I I 55 and $£$ I 753; in 1875 they were knocked down for $£ 950$ and $\delta 1732$, and for neither did the artist receive more than 30 guineas. There was an excellent series of fourteen examples of this artist in Peter Allen's collection, where some of the smallest and least important sold for over 50 guineas each; the highest sum, 265 guineas, going for the "Hay Harvest." In March I 892 his "Bolton Abbey" sold for 900 guineas. Some of the best examples of Copley Fielding's works came under the hammer in April 1889, when Mrs. Sarah Austin's collection of water-colour drawings was dispersed. Neither of the five examples, however, realised four figures, the largest amounts being $£ 903$ paid for the "Fairy Lake" and $£ 672$ for the "View from Box Hill." Quite a large number have also been sold during the past season or two, one of the best being Peter Allen's "Off the East Coast," for which 310 guineas were given.

Two very fine pictures of J. F. Lewis occurred in the Price sale, 1892 ; the wellknown "Lilium Auratum," which in the Quilter sale, I889, realised I05' 0 guineas, now fell to 810 guineas; while "The Bezestein Bazaar of El Khan Khalil, Cairo," 88 


\section{Pictures}

fetched rogo guineas. In April I 893 "The Hosh (courtyard) of the House of the Coptic Patriarch, Cairo," formerly in the collection of the late William Leaf, at whose sale in 1875 it went for 1850 guineas, dropped in 1893 to 1650 guineas. Probably the highest amount at which any example of this artist has been sold recently occurred in connection with "The Commentator of the Koran," which was painted for the late Sir William Bowman in I868, at whose sale, in June I 893, it fetched $255^{\circ}$ guineas. In the case of W. J. Müller, as of Lewis, very fair pictures have been sold during the past two seasons for from about 100 guineas to 400 guineas; but in I $888 \mathrm{Mr}$. Bolckow's picture of "Ancient Tombs and Dwellings in Lycia" by Müller realised the very high and perhaps maximum figure of $375^{\circ}$ guineas. Two other pictures by the same artist realised I 500 guineas each in the same year; but one of these, "The Bay of Naples" (1839), had sold for 2100 guineas in the Gillott sale, 1872. "The Opium-Eater," which in 1877 sold for 470 guineas, fell in May I893 to I 70 guineas. Mr. Price's example, "A Waterfall in Wales," sold for the respectable sum of 800 guineas; whilst the Hon. F. Baring's small picture of "Children Fishing, Gillingham," went for just half that sum in June I 893. Lord Cheylesmore's 
very small picture ( 8 inches by I I inches) sold in 1892 for 32 guineas, or nearly double the amount paid for it in 1868 . The public favour seems to have deserted for the time the works of Sir Charles Eastlake, W. Etty, and Sir A. W. Callcott. Etty's ambitious picture of Joan of Arc in three parts has changed hands on two or three occasions for very large sums, and roo guineas for either of the three portions would not be an extravagant price; in January 1893 , however, one of these compartments went for seven and a half guineas. The same artist's "A Bivouac of Cupid and his Company" realised 260 guineas at the Price sale; in 1845 it sold for 370 guineas, and in 1868 for 221 guineas. In April I 893 this artist's "Mars, Venus, and Cupid," and "Cupid," went for 230 guineas and $5 \mathrm{I}$ guineas respectively, neither of which amount can at all represent the original prices. In I 888 "The Judgment of Paris" and "The Triumph of Cleopatra" sold for $£_{504}$ and $£_{25}$, the previous prices being $£ 850$ and $£ 451$ respectively. Sir Charles Eastlake's picture of "The Sisters" sold in the Rogers collection for 420 guineas; in April 1893 it changed hands for 35 guineas, the same amount being paid in 1892 for the same artist's large canvas, "Gaston de Foix taking Leave of his Lady on the Eve of the Battle of Ravenna." In I 845 


\section{Pictures}

this rather striking work was appraised at only I90 guineas. Sir A. W. Callcott's picture of "Laurence and his Dog," which sold in the Brunel collection, I860, for 370 guineas, dropped in June 1893 to 42 guineas. The works of T. Webster, R.A., which at one time realised high prices, have also experienced a very general fall. For example, "Good Night," which sold in the Bicknell collection, 1863 , for $£ 1207$, ros., and in the Betts collection, 1868 , for $£ 877$, I 5 s., was sold with the Brocklebank pictures in 1893 for $35^{\circ}$ guineas. Lord Cheylesmore's example of this artist, "The Present to the Lady of the Village," dropped from 250 guineas in 1870 to 70 guineas in I 893 .

The works of C. Stanfield are by no means a steady article of commerce, and the general tendency is not at all upward; but quite a phenomenal exception occurred in Lord Cheylesmore's sale, 1892 , when the splendid picture of "St. Michael's Mount," which sold in 1870 for $25^{\circ}$ guineas, now ran up to 3000 guineas. Landseers differ almost as greatly in quality as in price. A unique series of thirty-three examples came up for sale with the collection of the late Lord Cheylesmore in May 1892, and affords an easy medium of comparison. The best pictures appear to increase in the same ratio 
as the less excellent examples decline. "The Monarch of the Glen," so well known through T. Landseer's very successful engraving, is a masterpiece, and is never likely to sustain any very pronounced depreciation in value. In the late Lord Londesborough's sale it fetched 6200 guineas, which amount was increased by 700 guineas in 1892 . On the other hand, the "Taming of the Shrew," which realised 1430 guineas, now dropped to I 50 guineas - not a serious drop, perhaps, considering the number of pictures by the same master sold at the same time. A much more serious fall, however, was experienced by "Lady Godiva's Prayer," which in I 874 was appraised at 3200 guineas, and was now sold for 900 guineas. "The Highland Cabin," which, in the Duchess of Bedford's collection in I853, went for I 50 guineas, now sold for 450 guineas; "The Sentinel," which sold in $\mathrm{I}_{4} 4$ for 240 guineas, now realised I 80 guineas; and "All that remains of the glory of William Smith," which, twenty years ago, went for $3^{20}$ guineas, was valued in 1892 at 290 guineas. As the majority of the other Landseers in this collection were purchased from the artist, no comparison can be conveniently instituted between their past and present values. As two further illustrations of the rise and fall respectively in Landseers, 


\section{Pictures}

we may mention "Taking a Buck," which in the Manley Hall sale, I 888, realised $195^{\circ}$ guineas, dropped in 1892 to 620 guineas; and "Braemar," which in I 868 sold for 4000 guineas, had advanced at the Bolckow sale, in 1888 , to $£ 5197$. The celebrated work, "Chevy," for which Landseer is said to have received $£ 5000$, realised in the Hemming sale in April I 894, 3750 guineas.

The pictures of Wilkie and David Roberts vary, like those of Landseer, in quality and price. The subject sometimes influences the latter, for subjects as well as schools have their vicissitudes. Lord Dudley's example of the latter, "Jerusalem, looking South," formerly in the Hootan Hall collection, dropped from 850 guineas in 1875 to 140 guineas in 1892 . On the other hand, this artist's very fine picture, with the legend, "Baalbec Ruins," had increased from $75^{\circ}$ guineas in 1813 to $£_{1627}$, ros. The wellknown picture entitled "The Letter of Introduction" of Sir David Wilkie, had increased in value from $45^{\circ}$ guineas in 1842 to $£_{2152}$, Ios. in May 1393 . First-class pictures by Wilkie and Roberts will probably always fetch high prices; but the few foregoing facts are a sufficient indication of the extent to which even the very best works of the most eminent artists fluctuate within the short space of forty years. The same rise 


\section{Pictures}

and fall occur in connection with the pictures of Turner. The vignette title of Killiecrankie, engraved in Sir Walter Scott's prose works, realised 200 guineas in the Novar collection, June I 877 ; in January 1893 it dropped to 66 guineas. The engraved drawing of Cassiobury, which realised $4 \mathrm{I} 5$ guineas in 1875 , had dropped to 330 guineas in June I 892. As a contrast, the masterpiece known as "Modern Italy: the Pfifferari," was knocked down in 1867 for $£ 3465$, in 1868 for $£_{2961}$, and with the modern picture of the Novar collection, 1878 , for $£ 5^{2} 5^{\circ}$, at which sum the late David Price became the owner. At his sale in 1892 it realised $f_{5460}$. "Helvoetsluys" brought 6400 guineas, and "A View of the Thames from Mortlake" 5200 guineas, in June I 895 .

The pictures of Peter Nasmyth and P. F. Poole may be considered together as representatives of the two most extreme instances of the rise and fall of pictures. Even the smaller works, which cannot at all be classed among the best of the former artist, are decidedly firm. The two examples which occurred in the Field sale in June 1893 came in this category; for the two charming little landscapes sold at 610 guineas and $35^{\circ}$ guineas had previously come under the hammer for 405 guineas and 390 guineas respectively. One of the very finest landscapes 94 


\section{Pictures}

of this artist, "A View in Surrey," measuring only $23^{\frac{3}{4}}$ inches by $33^{\frac{1}{4}}$ inches, sold in the Price collection for 2500 guineas, and another, "On the Firth of Forth," which is scarcely half the size, for 560 guineas. Poole's pictures, almost without exception, have fallen sadly in the estimation of buyers. They are carefully painted and perfect in nearly every respect; but the public taste has changed with regard to them, and they are to be had at about a twelfth of the prices originally paid for them. The half-dozen in the Price collection represent a very heavy balance on the wrong side in the late owner's picture bills. Although the elder Linnell's landscapes do not invariably maintain a high level, their general advance in public estimation naturally carries an enhanced value. Mr. Price possessed six works by this artist, and if the sums paid by him and received by his executors were placed side by side, the balance would more than justify his wisdom in purchasing them. For instance, "The Timber Waggon," which in 1880 sold for 850 guineas, in 1892 realised 3100 guineas.

The pictures by Dante Gabriel Rossetti, of which a dozen occurred in the Leyland sale, I 892, have probably reached their zenith. Only two, "Veronica Veronese" and "The Blessed Damozel," reached four figuresI000 guineas and 980 guineas respectively 
-whilst the well-known panel, "The Loving Cup," sold for 820 guineas. But the vagaries of fashion are strange and unaccountable, and the time may come when the distinctly genre works of Rossetti will prove a veritable gold mine to those who have speculated more or less heavily in this extremely hazardous commodity.

Of modern living artists whose works have fallen most grievously in the market, Mr. F. Goodall comes at the head. In the Murietta sale there were nearly three dozen examples, which sold at figures varying from 5 to 54 guineas; one of these, "A Bazaar in Cairo," which was bought in in $187 \mathrm{I}$ for 225 guineas, sold for 33 guineas. The well-known picture, “Brittany Peasants' Dance," which in 1879 sold for 760 guineas, in May last went for 325 guineas. "Rebecca at the Well," which at the Bolckow sale in 1888 realised 770 guineas, sold with Lord Cheylesmore's pictures last year for 555 guineas. There were six other important if small examples of Mr. Goodall's works in the last-named collection, but they were all purchased direct from the artist, and, as half-a-dozen of them showed a total of 457 guineas, it may safely be assumd that there was a heavy financial loss over the transaction.

Pictures by other living artists almost without exception fare ill so soon as they appear 96 


\section{Pictures}

in the auction-room, and we do not propose to enter into any exhaustive survey of this phase. A few illustrations, however, will be of general interest. One of the most notable drops occurred at the Price sale in connection with Sir John Millais' pre-Raphaelite freak, "Apple Blossom" (exhibited at the Royal Academy in 1859 under the title of "Spring"): in 1876 this picture sold for I 390 guineas; in 1886 it was appreciated at the diminished figure of 1000 guineas, whilst in 1892 it fell to 660 guineas. "St. Martin's Summer," which was bought in I883 for $E_{1365}$, was knocked down in I 888 for $£ 882$. The best examples of this distinguished artist's work generally run into four figures, as witness "The Sound of Many Waters," which was painted expressly for Mr. Price in 1876, and which sold in 1892 for 2900 guineas. "The Eve of St. Agnes," one of his most poetic works, sold for 2 I 00 guineas in I 892, and "Dropped from the Nest" for I 200 guineas in A pril I 893.

The works of Mr. Alma Tadema and Sir E. Burne Jones maintain almost uniformly high figures, particularly those of the latter, whose fine picture entitled "The Mirror of Venus" realised in the Leyland sale 3400 guineas, and whose "Merlin and Vivien" was sold on the same day for 3600 guineas. Two other pictures by this artist each realised 
I 350 guineas in the same sale, and it may be doubted if a similarly high level can be quoted in connection with a series of six or seven pictures by a living English artist. The six pictures by Mr. Alma Tadema in the Murietta collection realised sums varying from 455 guineas to I 400 guineas, at which latter amount "A Patron of Sculpture" was knocked down. "Fredegonda," which was one of the features of the Royal Academy of I380, sold in the Price collection for 980 guineas, but it was returned as somewhat damaged, and when again put up for sale in April 1893 it went for 750 guineas. The genre pictures of $\mathrm{Mr}$. Faed and $\mathrm{Mr}$. J. C. Hook maintain a high average - a fact with which no lover of truly conscientious work will complain. Mr. Faed's "Sunday in the Backwoods" sold for 790 guineas in 1867 , but in the Cheylesmore sale it advanced to I 700 guineas. Mr. T.S. Cooper has painted far too many pictures, with the very natural result that even his best examples realise a fall every time they occur in the open market. The same may be said of Mr. W. P. Frith, for some of the pictures by which he is best known appear to be the least appreciated when they come under the hammer. "Dolly Varden," for example, realised 1000 guineas at the Dickens sale, I870; in I 888 it was appraised at $£ 777$. "Bedtime" also 98 


\section{Pictures}

dropped from 410 guineas in 1854 to 138 guineas. "Claude Duval" sold for close upon $£ 2000$ in 1875 ; in I892 it dropped to 600 guineas.

The examples of the President of the Royal Academy from which a comparison may be drawn between their past and present prices are not numerous. During the season of I 893 only one example of Sir Frederick Leighton's more ambitious work has occurred in the market, namely, "The Daphnephoria," about which so much that was foolish was written and published at the time of its sale. This picture, which is 5 feet 7 inches by I7 feet, has been engraved, and was exhibited at the Royal Academy in 1876 . It realised 3750 guineas. It was immediately followed by two other examples of the same artist, "Sisters" and "Lieder ohne Worte," which realised 80 guineas and 160 guineas respectively. "Jezebel and Ahab meeting Elijah the Tishbite," which sold in I 882 for $£ 425$, realised II 5 guineas in July I 893 . Of the productions of a former P.R.A., Sir Francis Grant, examples are procurable for a very moderate consideration; by the way, this gentleman had the opulent courage to declare on one occasion that he had never heard of Hazlitt as an art-critic.

That pictures by the numerous class to which the term of ordinary artists may be 
applied should experience uncomplimentary falls in the auction-rooms is not surprising. Inability to paint is almost an accomplishment now-a-days. The dreary monotony of all our spring exhibitions is a sufficient proof of the prevalence of the painting epidemic; and the startling number of picture-shops, in which every phase of modern art is displayed, is a still further manifestation of the untiring efforts of the quasi-artists. The embryo painter no sooner begins to spoil good canvas than he almost immediately begins to manufacture pictures by the score. It is an appalling fact that these people make, in many instances, hundreds a year out of their dexterity : it is a much greater calamity that they consider themselves artists. Their patrons are all too easily deluded into the same belief. The latter pay comparatively big prices for articles which have no (or very little) intrinsic value or merit. The saleroom is the great leveller of all spurious claims. A year or so ago, at Christie's, a fairly well-known artist bought back, in the presence of the present writer, a picture for $£ 48$ for which the late owner had paid him 300 guineas. Still more recently a picture for which the late owner paid the artist $£ 50$ went a-begging for rather more than as many shillings. Similar instances might be quoted ad infinitum. The man of means with a 


\section{Pictures}

weakness in the direction of pictures is as fair game for the rising artist as for the enterprising philanthropist ; the greatest sufferers are the legatees, with whom disappointment in regard to modern pictures must be peculiarly keen and disagreeably common. So long as there are friends, relations, and a credulous public, so long will there be a plentiful supply of bad or neutral work in the guise of pictures. 



\section{Pottery}

$$
\text { and Porcelain }
$$





\section{Pottery}

\section{and Porcelain}

OF all tastes, that for pottery and porcelain has been from time to time the most prevalent. Indeed, if a census with the object of ascertaining what the inhabitants of Great Britain collect were taken, it would certainly be surprising to find how many people confessed to a weakness for china, as it is generically termed, or "china-earth," as it used to be called in the days of Charles II. We are all acquainted with Charles Lamb's essay on "Old China," where he expatiates on the corner-cupboard, the first object of his inquiries, he says, whenever he visited a house in the country. It was said of Horace Walpole: "China's the object of his soul." But it would be much more surprising to find how little the majority of its devotees really knew about it. China-collecting, however, is a fashion, and, like all other fashions, it has been carried to extremes. China, of all the various species of crotchets, has perhaps been the most widely diffused, because the 


\section{Pottery and}

surviving remains of the ceramic art are so vast, that every rural hamlet may have its share of perfectly genuine examples. At the same time the number of really fine and desirable objects, either in porcelain or in earthenware, is comparatively limited.

Pottery and porcelain have a very wide and a very deep interest, and when these two principal branches of the manufacture are properly studied, it will probably be found that they have manifold claims on our attention. It has been asserted that the productions of the ceramic art "more perfectly adapt themselves to the fashion of thought, to the fancies and ideas of each successive generation of men, than those of any other human industry." This statement has much truth in it. But the more prized (because the more rare) productions of the ceramic art ought to be regarded as antiquities, which is distinctly their proper category. An antiquary may be assumed to know the particular phase of past history in which he has taken a special interest, and it is he alone who understands the lessons and can best appreciate the progress and value of old pottery and porcelain. Probably very few persons who engage in the pursuit enjoy the opportunity or possess the inclination to enter into it with any measure of thoughtful study; and in the eyes 


\section{Porcelain}

of the majority of those who gather ornamental objects for their dwellings or cabinets, old china falls loosely under the categories of being pretty or ugly, cheap or dear. Of the country of origin, of the epoch of manufacture, of the comparative value and interest, the average man knows little enough. His information is confined to general outlines. $\mathrm{He}$ has heard of Christie's, of old blue, of hard and soft paste, of Wedgwood, and a few other letters of the ceramic alphabet. It is precisely on all fours with books, coins, and pictures: as many as you can count on your fingers are judges, and the rest dabble; while the critic, who prides himself on quickness of study, is often found referring to the science in depreciatory terms from a cursory survey of the specimens in shop-windows or in the hands of a friend.

This is the only craze taken up, or at least condoned, by ladies, and one's natural gallantry ought perhaps to prevent one saying hard things about it. China-collecting among women at one time denoted unusual strength of mind and absence of nerves, as is shown by Pope's lines in his second "Epistle" "addressed to a lady":-

"Oh! blest with Temper, whose unclouded ray Can make to-morrow cheerful as to-day; She, who can love a Sister's charms, or hear Sighs for a daughter with unwounded ear; 


\section{Pottery and}

She who ne'er answers till a Husband cools, Or, if she rules him, never shows she rules, Charms by accepting, by submitting sways, Yet has her humour most when she obeys; Let Fops or Fortune fly what way she will, Disdains all loss of Tickets or Codille :

Spleen, Vapours, or Small-pox, above them all, And mistress of herself tho' China fall."

Addison, in the tenth number of The Lover, has touched on the subject of women's passion for china in his usual exquisite humour. "There are no inclinations in women," he observes, "which more surprise me than their passions for chalk and china. The first of these maladies wears out in a little time; but when a woman is visited with the second, it generally takes possession of her for life. China-vessels are playthings for women of all ages. An old lady of fourscore shall be as busy cleaning an Indian Mandarin as her great-grand-daughter is in dressing her baby." "How much anger and affiction are produced daily in the hearts of my dear countrywomen by the breach of this frail furniture. Some of them pay half their servants' wages in china fragments, which their carelessness has produced." Addison quotes a dictum of Epictetus apropos of this temper-trying contingency: "If thou hast a piece of earthenware, consider that it is a piece of earthenware, and by consequence very easy and obnoxious to be broken. Be I08 


\section{Porcelain}

not, therefore, so void of reason as to be angry or grieved when this comes to pass." Addison concludes a very delightful paper with the reflection that, "did our women take delight in heaping up piles of earthen platters, brown jugs, and the like useful products of our British potteries, there would be some sense in it. They might be ranged as fine figures, and disposed of in as beautiful pieces of architecture; but there is an objection to these which cannot be overcome, namely, that they would be of some use, and might be taken down on all occasions to be employed in services of the family; besides that they are intolerably cheap, and most shamefully durable and lasting."

During the last forty or fifty years many very extensive collections have come under the hammer at Sotheby's and Christie's. In the Bernal sale of 1855 , one day's sale of porcelain brought over $\mathcal{E}^{6} \mathrm{I} 33$. Mr. Gladstone's collection-perhaps one of the most representative of its kind as illustrating the history of the ceramic art-of 382 lots, sold in 1875 , fetched nearly $£ 5000$, of which a handsome percentage represented homage to the current fame and standing of the owner, as the property was very indifferent. This was exemplified by the Bohn sale, a far larger and far superior one, bringing, a year later, only about $£ 8000$. In 1879 Lord 
Lonsdale's china and other decorative objects sold for over $£ \mathrm{I} 9,000$, and in the same year the porcelain of $\mathrm{Mr}$. Charles Dickins, of Sunnyside, Wimbledon, sold for over $£ 6000$; in I 888, the majolica of Lord Hastings sold for over $\delta 14,459$. But the highest point was reached at the Dudley sale in $\mathrm{I} 886$.

We may regard the Chinese (and Japanese) pottery and porcelain as the most ancient. The Orientals themselves fix the first fabrication of the potter's art to a period of about 2700 years before the Christian era, whilst the invention of porcelain is quite modern according to Chinese chronologists. The Emperors of China appear to have been great patrons of ceramic art. Pottery is said to have been invented by Hwang-ti, who ascended the throne in 2698 B.c., and Yu-ti-shun made pottery before succeeding to imperial dignities in 2255 B.c.; but it is not certain that porcelain was known before 87 or 88 A.D., and was then probably only stoneware. An important year was 583 A.D., when a special decree ordered the potters of the district now known as King-te-chin to make porcelain for the Emperor's use. The origin of blue china is placed at between the years 954 and 959, and it is said that the Emperor Chin-tsung being asked his pleasure as to the porcelain articles for royal use, replied, "In future, let them be blue as the 


\section{Porcelain}

sky that one sees after rain between the clouds." For these and other appreciations of the art during subsequent periods, present enthusiastic collectors are doubtless grateful while they look with pride upon their possessions. It is quite certain that the Orientals were centuries ahead of us in this matter. Of all the several classes of porcelain collected, old Chinese and Japanese enjoy the greatest share of popularity. But the most ancient examples both of China and Japan are not the most attractive. Their chief value is that they form an interesting chapter in the history of the art, and when that has been said, not very much else can be urged in their favour.

An exceedingly interesting exhibition of blue and white porcelain was held at the Burlington Fine Arts Club in February last, when many choice specimens were lent by the leading collectors of this country. "Blue and white" is certainly a ware which can only be appreciated through acquaintance, and that that appreciation has greatly extended during the last decade or two is proved by the fact that vases which might have been purchased some years ago for a few sovereigns are now valued at nearly a thousand pounds. Three or four pieces in this exhibition which came from the Burghley House collection are believed to have been in the possession of 


\section{Pottery and}

the family from the time of Queen Elizabeth. They were lent by Mr. Thomas Agnew, who insured them for no less a sum than $£ 3000$. The probability is that it was in the seventeenth century that the finest period of art and fabric was reached in the East.

Some astounding prices have been paid at different times for various descriptions of porcelain. Among the many objects of art collected by Lord Revelstoke and sold in I893 were a pair of octagonal Mandarin vases and covers, of old Chinese porcelain, enamelled with flowers, birds, and insects, four feet in height, which sold for 1000 guineas; also a set of three old Japan vases and covers, and a pair of beakers, painted with chrysanthemums, other flowers, and buildings, in dark blue borders (the vases were 34 inches high and the beakers 24 inches high), and the lot, which last year realised 270 guineas, had been bought from Madame de Gruytens of Antwerp, whose father purchased them from the family of Rubens. At the Murietta sale, three and a half years ago, a pair of old Japan jars, richly decorated with fruit, trees, flowers, \&c., 30 inches high, went for 230 guineas. But in each of the foregoing examples the purchaser had at all events something for his money so far as regards size. In the Field sale of June I893, a pair 


\section{Porcelain}

of oviform vases, of old Chinese lavender porcelain, painted with bamboos and foliage, in dark blue and red, I 3 inches high, realised the preposterous sum of 590 guineas. But for foolishly high prices one has to go back to the sale, in 1880 , of Dr. E. B. Shuldham's collection of blue and white porcelain, when one old jar was knocked down for $£ 620$, and another at $£ 650$, and in neither case was the reserve price reached. In April 1894 the collection of Mr. E. O. Arbuthnot of Shanghai was sold in New York, and 220 dollars were given for a soft paste semi-eggshell pear-shaped bottle, 22 inches high; a set of four peachblow coupes - the glazings and shadings were different in each piece, and the set represented the varying hues of the ripening peach, each measured $4 \frac{3}{4}$ inches by $1 \frac{1}{2}$ inch-realised 560 dollars. At the same sale a Lang-yao crackle vase, I $6 \frac{1}{2}$ inches high, sold for I 290 dollars; and a long, slender-necked Hawthorn bottle, of which only two others of the kind are known to exist, fetched 620 dollars. From these prices it will be assumed that the mania is as pronounced in America as it is here; but if any further proof is needed here are a few more lessons from a sale held in the same city in May 1894, when Captain Brinkley's collection came under the hammer. A large vase of soft paste, of light 
buff colour, I 8 inches high, "over 900 years old," bought in Shanghai by the collector, 2400 dollars; a small vase of Ting Yao ware, " 850 years old," realised 525 dollars; a vase of the same ware, $15^{\frac{2}{3}}$ inches by $25 \frac{1}{2}$ inches in circumference, deep cherry-red colour, with white shadings on one side, I 375 dollars; a blue and white jar of the Hawthorn pattern, 650 dollars; a pair of plates, 440 dollars; a vermilion box, $4 \frac{1}{2}$ inches wide, 300 dollars; whilst a I7-inch vase, whose broken neck had been replaced by a silver cap, 500 dollars. A collection of I 5 I lots realised a total of 22,000 dollars! Specimens of genuine porcelain were brought to England early in the sixteenth century, and they then realised very high prices. The examples above quoted are probably of or about that time. Since the sacking of the Summer Palace at Pekin in I 860, and the opening up of Japan after the troubles of 1862 , the exportation to this and other European countries has been enormous. Oriental porcelain consequently has become common; but the genuine ancient ware is more valuable than ever, and is easily distinguished from that which is imported as an article of merchandise into Europe. The Orientals themselves do not make any longer such pieces, the cost of the material being too great, and they are even prepared to 


\section{Porcelain}

purchase back the inimitable productions of their ancestors, who bestowed on the labour an amount of time and outlay no longer consistent with commercial ideas or possibilities.

Next to Oriental porcelain in historic importance, but far before it in general cash value, comes old Sèvres. And here, as elsewhere, the collector's idiosyncrasies outrun his artistic instincts. The occurrence in the market of a specimen of the soft porcelain of the early Sèvres period is quite enough to send most collectors into a frenzy of excitement. It realises outrageous prices. It is curious to reflect that a century and a quarter ago true china was unknown at Sèvres, so far as being manufactured there was concerned. Since 1769 , and indeed within a very few years of that period, it had achieved a world-wide fame. But revolution after revolution in France took place, kings came and went, before examples of the Sèvres manufactory commanded fancy figures. The finest period is about 1775, and the two peculiarities of the real pâte tendre are a certain unctuous surface and a studied irregularity in the decoration. In I874 (July I2) a set of three vases of the rose du Barri Sèvres, consisting of a centrepiece as a vaisseau à mât and two eventail jardinières, belonging to the Earl of Coventry, and modestly styled "a garniture 
de cheminee," realised the record price of $£ 10,500$. They were bought by the Earl of Dudley, who, a short time afterwards, paid $£ 6825$ for a pair of vases with openwork covers and stands of gros-bleu, green, and rose, of rare form, painted with rose $d u$ Barri foliage and Chinese figures. This pair of vases measured II $\frac{1}{2}$ inches in height.

The garniture de cheminée is unquestionably one of the greatest triumphs of Sèvres work, and its history may be here told, inasmuch as it appeared at Christie's again so recently as July of the present year. The set is known as the "Coventry Vases," and these unique specimens of ceramic art were made in 1759 . They were presented by Louis XV. to George William, sixth Earl of Coventry, who married in $175^{2}$ one of the beautiful Miss Gunnings. The centrepiece, which is modelled to represent the arms of the city of Paris, is $14 \frac{1}{2}$ inches high, whilst the two jardinières are $8 \frac{1}{2}$ inches high. The rose du Barri ground is combined with green, and is a perfect example of this scarce combination; the paintings are admirably copied from Teniers' well-known subjects, with groups of exquisitely painted flowers, by Morin, in the reverse. This set passed from Earl Dudley's possession into that of the late W. J. Goode, at 10,000 guineas. Mr. Goode's object in paying so II 6 


\section{Porcelain}

high a price for this set was purely a commercial one, to see, in fact, how closely they could be copied at his potteries. It is interesting to point out that the two copies which he made are as like the original as the proverbial "two peas in a pod." These copies, of which one only is taken up, are priced at $£ 300$ each, or about the actual cost involved in reproduction. The original set was, as we have said, offered at Christie's in July last, but was bought in at 8000 guineas.

The two gros-bleu vases, for which Lord Dudley paid $£ 6825$, were bought in at the Dudley sale in 1886 , the highest offer being $£ 2625$.

Again, a set of three éventail jardinières of the largest model, green ground, painted with birds and flowers, by Alonde, which sold in Lord Dudley's sale in I 886 for I 668 guineas-they cost him EI995-dropped to 1470 guineas when they appeared in Lord Revelstoke's sale in I893, where also a rose $d u$ Barri jardinière of the largest model, with white and gold scroll handles, sold for I050 guineas; a pair of green éventail jardinières, each painted with tropical birds and flowers on white ground, went for 480 guineas, and a pair of rose du Barri square jardinières $6 \frac{1}{4}$ inches high, fetched 2 10 guineas! Among the Cassiobury Park treasures, collected in France soon after the 


\section{Pottery and}

great French Revolution by the fifth Earl of Essex, and sold last year, an oviform vase and cover on gros-bleu ground, and painted with a seaport and marine trophy in colours in medallions by Morin, 15 inches high, realised the extraordinary sum of 1900 guineas; a garniture of five sea-green vases, with birds and plants in dark blue and colours, each about $14 \frac{1}{2}$ inches high, realised I 400 guineas, and many other items sold for equally extravagant amounts. At the Hodgson sale at Christie's in I893, among the old Sèvres were sixty-six white plates with blue lines and gilt edges; these plates realised over three guineas apiece. Even as far back as 1855 certain examples of old Sèvres ran well into three figures, for at the dispersion of the Bernal collection in that year a pair of rose $d u$ Barri vases, I $4 \frac{1}{2}$ inches high, with plinths, sold for $£ \mathrm{r} 492$, IOs., and a pair of vases, turquoise, for $£_{14}$ I 7, IOs., the purchaser in each case being Lord Hertford. But probably never before and only once since did Sèvres porcelain realise such absurd prices as at the Hamilton Palace sale in 1882 ; collectors were carried away by the great fame of this extraordinary collection. We have only room to mention two illustrative examples: a vase and cover, turquoise ground, with white and gold bands and festoons of foliage, $13^{\frac{1}{2}}$ inches high, $£$ I585, and an oval plateau, gros-bleu fes- 


\section{Porcelain}

toons and medallions, imitating moss agate, I I $\frac{1}{2}$ inches by $8 \frac{1}{2}, £ 430$. An interesting item in Sèvres occurred in the collection of Dr. Patrick Sinclair Laing, sold at Sotheby's in February I893: a pair of vases and covers of rich bleu ground, painted with portraits of the Empress Catherine of Russia, and interlaced letters forming monograms of the King of France and the Empress, with crowns in gold above; this lot sold for $£ 99$.

Next to the Sèvres, of which the modern specimens are not sought, probably Dresden porcelain is the most in favour with collectors. One of the most extensive collections which has come under the hammer in this country was that of the Duc de Forli, a Neapolitan gentleman, sold at Christie's in I 877, realising a total of over $£ 422 \mathrm{I}$. An "écuelle" in Mayflower, painted with Watteau figures and the arms of the Dauphin, realised 300 guineas! A little lady in a hooped petticoat and her two pet pugs realised $\Varangle_{2}$ I 5 ; whilst a pair of small candlesticks sold for 100 guineas; a pair of bulls attacked by dogs, $6 \frac{1}{2}$ inches high, for $£ 195$; an inkstand formed as a galley, with a seated figure in the stern, $£ 94$, IOs.; a coffee-pot, 100 guineas. At Christie's in March I 894 an old Dresden service of 163 pieces, each painted with different views in Holland in the centre, with red and gold scroll borders, was sold in 28 
lots, and realised the respectable total of $£ 333$, IOs. 6d. This service was formerly the property of a King of Holland, subsequently passing into William Beckford's famous collection. An old Dresden service, consisting of seventy pieces, was sold at the Hodgson sale in July I 893 for 370 guineas; but one of the highest prices of late years was paid at the Field sale of June 1893, when a pair of oviform vases and covers of old Dresden, each painted with garden scenes and figures in two medallions on white ground, with forget-me-nots in relief, I 4 inches high, realised $£ 94.5$.

Struck by the beauty of the work of the Moorish potters in Spain, the Italians first imitated and then far excelled their neighbours. At Gubbio, for example, the method of imparting the very beautiful and unique ruby lustre to pottery was invented, but it never extended beyond that town and Urbino, and the art is now lost. The majolica ware of both these places has much to commend it, and good examples fetch very high figures. Probably the most extensive collection of Urbino and Gubbio ware sold during the last few years occurred in the Spitzer sale two years since. A Gubbio plate with paintings by Giorgio Andreoli, I 524, 16 inches in diameter, realised over $£ 1000$; another similar example, I 525, I I inches in diameter, 


\section{Porcelain}

sold for about $£ 250$; a cup of the same ware, I 536, 8 inches in diameter, realised 200 guineas, but a second cup of Gubbio, 1595, not 1o inches in diameter, sold for close on $£ 700$; a small plate, rather over 9 inches in diameter, realised over $£_{2} 50$. These articles fetch more in Paris than they probably would in this country.

In the sale of the effects of the late $\mathrm{E}$. Joseph, of Bond Street, in February I894, several very good examples of the Urbino ware came under the hammer: an oviform ewer, the handle formed as a grotesque male figure, I $2 \frac{3}{4}$ inches high, realised 195 guineas, and an oviform vase, with upright twisted serpent handles, 24 inches high, sold for I9 I guineas.

At the Spitzer sale, however, the prices paid were almost fabulous: a pair of vases, I I inches high, realised about $£$ I 300 ; a cup, Io inches in diameter, 1538 , went for $£ 280$; whilst a plate, $9 \frac{3}{5}$ inches by 20 inches, brought over $£ 500$, and a basin, 18 inches in diameter, $£ 250$. The highest price for a single piece was paid for a plate 20 inches in diameter, which realised close on EI 300 . The Hispano-Moresque ware, the most splendid and beautiful example of which is probably the celebrated vase at the Alhambra, does not, as a rule, realise such high prices as the examples of Italian 


\section{Pottery and}

majolica just quoted, but a plate of the best period fetches $£ 200$. Examples of the Caffagiolo ware of the fifteenth century realise very high prices sometimes, as in the Spitzer sale, when four plates, from I 3 inches to 17 inches in diameter, realised a total of about $£ 6600$ ! Genuine examples of the royal porcelain works established by Charles III. of Naples at Capo di Monte are exceedingly pretty, and realise very high figures. Among Mr. Gladstone's collection of china sold in 1875 , four Capo di Monte groups of the quarters of the globe realised fII 5 ; but in the Joy collection sold three years ago at Sotheby's, a cup and saucer of this ware, formerly in the Bernal collection, sold for $£ 8,12$ s., and a milk-jug and teapotthe latter having a view of Puteoli on a canary ground-realised only $£ 6$. These pieces are copied from the Buen Retiro china, but are almost opaque, instead of being unusually transparent like the originals. The Capo di Monte work in relief is best known from the common reproductions, the moulds being in existence, but the old pieces are easily distinguished. The productions of the ordinary Spanish type are the earlier, and are by far the rarer; they are sometimes sold as Buen Retiro.

The "Henri Deux" ware was manufactured between the years I 540 and I 560 , probably in Touraine. Its existence was 


\section{Porcelain}

quite forgotten until I 839, when M. André Pottier first announced it to the world. When one piece had been discovered others naturally turned up, but only about fifty examples have been found, and of these the majority are in England. This pottery is regarded by those who have educated themselves up to it as of exquisite decorative quality and design, but to the lay mind its thin, yellowish-green appearance, with its "surface seemingly inlaid and encrusted with the innumerable details of elaborate ornamentation, made out in quiet browns, blacks, and sad neutral tints," is about as unlovely and inartistic as anything could well be. But it is impossible to deny that from a technical point of view it is of great interest, inasmuch as its fabrication displays novelties of a varied character, into which we need not enter; it is the work of an original artist, with whom the secret was born and with whom it died. The finest example of this ware yet known, a ewer or aiguière, was purchased at the sale of M. Odiot, a silversmith and well-known collector of Paris, in I 842. It is beautifully engraved in Shaw's "Decorative Arts of the Middle Ages," and for a second time came up for sale among the renowned collection of works of art formed by the late Hollingworth Magniac, and dispersed at Christie's in July 1892 . 


\section{Pottery and}

Its extreme height to top of handle is $14 \frac{3}{4}$ inches, and the greatest diameter of the oviform body is $5^{\frac{3}{4}}$ inches. It was knocked down for the extraordinary sum of $£ 3990$ ! Two very characteristic examples of this fä̈ence, a tazza and a salt-cellar, were purchased by the Duke of Hamilton in 1859 for $£ 360$. At his sale in 1882 they realised I 960 guineas. Three pieces occurred in the Fountaine collection sold at Christie's in 1884 , and of these a flambeau realised $£ 3675$, the purchaser being a Frenchman, and a mortier à cire, which sold for £I 575 .

Of porcelain made in England, the Chelsea, the Bow, the Bristol, the Worcester, and the Derby are probably the best known and the most admired, or at least appreciated. In the British Museum there is a pair of Chelsea vases of the largest size, deep blue ground, painted with / exotic birds, formerly the property of Sir Hans Sloane. At Lord Dudley's sale in I886, two pairs of oviform vases and covers of old Chelsea ware, of extraordinary size, deep blue ground, 24 inches high, were knocked down at 2000 guineas per pairbut neither, it is believed, was really sold. A single vase of the same ware, painted in six medallions, I 7 inches high, realised $£_{946}$, whilst a pair of vases, covered with Watteau subjects in deep blue borders, I 6 inches high, sold for £IO7I. In another collection 


\section{Porcelain}

recently sold, an old Chelsea tea service, painted with exotic birds and deep blue bands, brought nearly $£ 900$ - the milk-jug alone selling for $£_{71}, 8 \mathrm{~s}$., or five times its weight in gold-whilst the cups and saucers, sold in pairs, varied from 40 guineas to 60 guineas per pair. After such figures it is almost absurd to refer to a pair of dark blue bottles of old Chelsea, $9 \frac{1}{2}$ inches, which realised 95 guineas in April I 894 at Christie's. Some extremely fine groups of Chelsea porcelain were formerly in the hands of $\mathrm{Mr}$. Sanders of Chiswick ; and at Holland House is the tea service presented by the factory to Dr. Johnson. It should be stated that there are of Chelsea two distinct epochs, of which the later is the finer, probably from the proprietors having then taken Italian artists into their employment; and the mark itself, an anchor, was borrowed from Venice.

Some well-known specimens of Bristol china were included in the Joy collection sold at Sotheby's three years ago, when a teacup and saucer of the celebrated service made by Champion in 1774 , and presented to Mrs. Burke, realised $£ 60$; whilst a cup and saucer made by Champion, at the request of Edmund Burke, for presentation to the latter's hostess, sold for $£_{24}$. The Edkins sale at Sotheby's yielded the finest collection of this class ever brought together. The 


\section{Pottery and Porcelain}

products of Bow have become more numerous as time elapses, and some very fine examples not unworthy of Chelsea are known. The mark usually found is a dagger and an anchor, but many specimens are unsigned. One of the "triumphs" of that pottery, an inkstand, painted with daisy pattern, I750, sold in 1892 for $£ 22$.

The best examples of Worcester and Derby are fully comparable with Chelsea. At Viscount Clifden's sale, on 7th May I 893, a set of three old Worcester vases, about 14 inches high, each painted with two large medallions on dark blue ground, sold for $£ 336$. In the same month also the celebrated dinner service of old Worcester porcelain (consisting of upwards of 260 pieces) presented by the British nation to Lord Nelson, was sold by order of the then owner, the Earl of Erroll. This service was divided into 62 lots, and realised a total of over EII54. Each piece is painted with a portrait of Lady Hamilton, as "Hope," in varied attitudes on the seashore. In such a case as this, the value is in a great measure a sentimental one. It is a sufficiently familiar fact that the Chelsea factory merged in that at Derby, and that the earliest work bears a $D$ charged with an anchor. Of the Worcester china we have three important epochs : the Wall, the Chamberlain, and the Flight. 



\section{Postage Stamps}

In the autumn of 1862 appeared at Brighton, from the pen of Mr. Frederick Booty, or rather from that gentleman's hand, for he was the artist likewise, a small octavo volume of forty-six leaves, of which the reverses are blank, and which is entirely lithographic, entitled, "The Stamp Collector's Guide : Being a List of English and Foreign Postage Stamps, with 200 Facsimile Drawings, by Frederick Booty." This is a book in comparison with which Caxtons are common, and which enjoys, we think, the proud advantage of being till this very instant unknown to bibliographers. It looks as if it might have been originally offered at sixpence; its present value is about $£$ I000, to borrow the phraseology of the Philatelic Vendor, and the price is somewhat enhanced by an indifference to orthography, punctuation, and artistic refinement. All these characteristics appertain to the true editio princeps, and establish its authenticity.

Now Mr. Booty, in an introduction, which, by the way, occupies both sides of the 


\section{Postage Stamps}

two leaves on which it is contained, opportunely tells us at the very commencement that whereas collectors in this line were (then) a short time since numbered by units, they had so increased in $\mathrm{r} 862$ as to be countable by hundreds; he does not see why even the more unlovely of postage-stamps should not possess a latent beauty (mark the happy expression !); yet he does not wish us to regard too exclusively the æsthetic side, for, as he says, the pursuit has its usilitarian (sic) one. Mr. Booty himself owed his knowledge of Queensland to its blue twopenny, besides a great deal more, and assures Dr. Browne, a coeval teacher of youth, that he is not the only person who had benefited by the new science, as it was at that date.

But in 1862 it is evident that stamp-collecting was chiefly, if not almost exclusively, a passion among schoolboys and schoolgirls; and when we think upon it a little, it was a period of European and Colonial history when many vital changes had occurred, or were occurring, in the political constitutions of States. The system of Postage had of course been long established, and prior to the Booty Hegira there had been ample time for numberless revolutions in Governments at home and abroad, and for consequent phenomena in the shape of new stamps. It would perhaps hardly be accurate to say 


\section{Postage Stamps}

that in the eyes of the Philatelic Vendor Great Britain holds the lowest rank, but certainly, owing to the deplorable permanence and stability of Her Majesty's Government, and the unreasonable longevity of the Queen, the rarities in the series seem hardly worth mentioning. Our poor country may well blush when it looks at the prices which the Philatelic Vendor declares himself ready to pay for the products of Hawaii, or some decently behaved Government which existed only long enough to issue six philatelic examples, of which three are more or less imperfect, or variants of unsurpassed curiosity and incalculable worth. If they resemble a defective post-mark impressed on a piece of blotting-paper, what of that? If the execution is criticised by the youngest member of your household as inferior to his own capabilities, do not be discouraged; give the Philatelic Vendor his thousand sovereigns, and thank him.

To return, however, to the presumed genesis of the thing, we seem to perceive that in I 862 a large accumulation of postagestamps existed up and down, belonging to several living Governments, and, which is much more, to a considerable number of defunct ones; and besides, at that juncture constant modifications were occurring, sometimes from year to year, in parts of Europe, 


\section{Postage Stamps}

South America, the West Indies, Australasia, Polynesia, and elsewhere. The pursuit was mainly limited to youngsters, Mr. Booty informs his readers, and it is easy to imagine the havoc which was always going on where the market value was low and the customer careless and inexperienced; just as when early printed books were very cheap, it was almost an economy: to light your kitchen-fire with them.

So it happened, we humbly conceive, that about the Booty era the increasing stir and talk in the family circle about stamps caught the ear of papa, and papa thought to himself, "Why should not I go and do likewise?" A schoolboy once received a gift from his uncle of a handful of worthless old coins in a canvas bag; he knew nothing about such matters, nor cared; but his father cast his eyes upon the poor little hoard, and was struck by the interest in the subject, even there nebulously perceptible. It is true that he threw the contents of the bag away, but the accident led to the formation of not the least important numismatic collection in Europe. We merely relate this anecdote because it has the air of a parallel. The philatelic furor, as it became, spread from the sons and daughters of England to her richer, if not wiser, sires; and as we write, there is, relatively speaking, no class of comI 32 


\section{Postage Stamps}

modity which is so eagerly sought, for which such ambitious prices are demanded and given, and in which the opportunities of obtaining that gratification on both sides which is so well described in the lines of Butler's Hudibras-

"For sure the pleasure is as great

Of being cheated as to cheat,"

are so frequent and so unfailing.

There are at least two thousand stamp dealers in Europe, and the number of people who make a living directly out of this calling is estimated at five figures. In London last season from $£$ I 5,000 to $£ 20,000$ worth of stamps were sold under the hammer by three or four auctioneers. One dealer retired after having accumulated, it is said, the very respectable fortune of $£ 50,000$. The "trade" in London is represented by nearly a dozen journals, and its literature could only be indicated by a portly volume of bibliography. The composition of the Philatelic Society of London is interesting, for among its members are many eminent and distinguished men (to say nothing of four ladies) whom the general public would little suspect of a weakness for such unconsidered trifles. The President and Vice-President respectively are the Duke of Saxe-Coburg-Gotha and the Duke of York. Its list of ordinary members 


\section{Postage Stamps}

includes one prince, two earls, a whole host of military and naval officers, and the remainder is chiefly made up of Esquires. In the autumn of I892, Mr. Castle, editor of The London Philatelist (the official organ of the Society), issued to I 6 members of the Society residing in Great Britain a series of queries concerning their particular collections, and from the tabulated replies we glean that the stamps in the possession of the rog who replied to the circular amounted to over 825,000 . The value of one collection was placed at $£ 10,000$, a second at $£ 6000$, two at $£_{5000}$, two at $£ 4000$, eight at amounts varying from $£ \mathrm{I} 200$ to $£ 3000$ each, and ten, at $£$ I000 each. The estimated value of the collections of ordinary members of the Society resident out of Great Britain is placed at $£ 100,000$, to which we have to add several of the largest holders, and notably that of Herr Philip von Ferrary of Paris, which has been computed as alone worth as much as the sum just mentioned. These figures do not take any account of the stocks of dealers, who are stated to be ineligible to the Society. It will be at once seen that to be a stamp collector on a dignified scale a man must be rich.

The Ferrary collection is in a way unique. This gentleman purchases at any price, we hear, examples of which he has no specimens, 


\section{Postage Stamps}

and has had for years two specialists devoted to the custodianship of his collection, at salaries of $£ 400$ a year. Another Parisian collector is said to possess over a million stamps preserved in a hundred and thirty richly bound volumes. The Tapling collection, valued at $£ 60,000$, and now in the British Museum, is supposed to rank second to that of Herr von Ferrary. The late Czar of Russia had a very fine collection, valued at about $£ 30,000$, and took a very personal interest in his stamps, particularly those of Asiatic issue. The Prince of Wales, as well as his brother and son already named, has a good collection. Her Majesty also has a good collection, one of the greatest rarities of which is an example of the first Garfield issue of the United States; and the Prince of Wales adds himself to the roll in a measure, but not so as to be viewed by Philatelic Vendor aforesaid as a grandee of the first class.

Stamp collecting is supposed to have originated in Belgium, and to have quickly spread to Germany and France, in the latter of which, not unnaturally, it developed almost into a public scandal. The infection appears to have soon found its way into England, and early in 1862 an informal kind of Exchange had established itself in Birchin Lane, London, which became such an unmitigated nuisance, that it was put down by the police, as a

I 35 


\section{Postage Stamps}

similar institution on the Boulevard Sebastopol had been suppressed by the Parisian authorities. Between I840, when stamps were first issued, and I860 two thousand four hundred examples of various kinds had appeared; by 1870 that number had increased to six thousand four hundred. The earliest systematic "Handbook" of the subject, closely following on the Booty monograph, was by Dr. J. E. Gray of the British Museum; the first edition of a thousand copies of this little book of fifty-four pages was sold out in twenty days, and five subsequent editions (the fifth extended to two hundred and twenty-six pages) appeared in rapid succession. On Ist April 1863-a somewhat unfortunate date-a Stamp Collector's Magazine appeared, and existed for twelve years. The movement scored another advance on 18th March 1872, on which date the first stamp auction was held at $\mathrm{I} 3$ Wellington Street, Strand, when the cream of the stock of J. W. Scott \& Co. came under the hammer, and realised a total of $£ 25^{8}$, the two highest individual figures being $£ 6$ for a St. Louis 20 cent, and $£ 8$, I 2s. for a variety of the same: This may be the fittest place for adding that since that time several auctioneers have instituted periodical night sales devoted to the same object. 


\section{Postage Stamps}

The day for forming a complete collection of stamps is passing away. Nearly every collector is now primarily a specialist, but the majority keep a more or less wary eye open to completing their collections so far as it remains possible. Most collectors restrict themselves to their own country; in England the demand is greatest for the stamps of Great Britain and its Colonies ; in America the United States stamps are most in request, and realise consequently better prices there than elsewhere. Beyond this general rule, fashions in stamps vary as often and as rapidly as fashions in other things. The other day the rage was for the postage stamps of Australia; now old and scarce Europeans, especially unused, and early Colonials, particularly those of the West Indian Islands, the Cape of Good Hope, and Mauritius, are the mode. One or two eminent collectors take up a particular line, and the others follow. Fashion has to be complied with in all matters. Then, again, certain collectors devote their energies to the juxtaposition of the various shades of particular issues, the gradations, for instance, from light red to dark red-and these variations sometimes number half-a-dozen in one issue. That such differences merely arise from accidents in the printing. processes or from chemical agencies, is perfectly immaterial. When stamp collect- 


\section{Postage Stamps}

ing narrows itself down to this species of hair-splitting, it unquestionably becomes a mania, as it does when it comes to measuring the margins and counting the perforations. A different perforation or the fraction of an inch more margin may vastly enhance the value of a stamp. One can sympathise with the very natural desire for a complete and perfect stamp, just as one prefers a perfect to an imperfect book, but when it becomes necessary to provide one's self with a "stamp measure," which splits an inch up into twenty-five sections, or with a "perforation gauge," the sublimity of the philatelic craze seems to verge upon the ridiculous. With all these bewildering contingencies and side issues, the edifying hobby of the schoolboy receives a fatal blow. The man who pays $£ 50$ or $£ 100$ for a stamp may have the satisfaction of possessing something for which he has been looking for many years, or of something which no one else can show; but what is his real unalloyed pleasure compared to that of the schoolboy who adds a dozen mediocre stamps to his modest album?

There are about a dozen stamps whose rarity has achieved for them a fame which would certainly be denied on any other score. That this number should be actually worth, in the open market, $£ 2000$, is a fact which almost takes one's breath away. Curiously 


\section{Postage Stamps}

enough, not one of these items is a thing of beauty; on the contrary, they are almost as ugly and inartistic as it is possible for such things to be--and that is saying a good deal. The nominal value of these at the time of issue would be about half-a-crown. A poor book collector may be pardoned for fancying what magnificent additions he could make to his shelves with this money. A big, in fact the biggest, slice in this total of $£ 2000$ is swallowed up in the purchase of two unlovely stamps, the Id. and 2 d. "Post Office, Mauritius," of the first issue, which appeared in September I 847 . It is probable that not more than eight sets of these stamps are in existence, and in only two or three cases do they occur together. The last pair sold were first acquired by Madame Dubois of Bordeaux, having been found in a merchant's office there. This lady sold them in 1867 to M. E. Lalanne, who, in his turn, recently disposed of his collection (including this pair) for 60,000 francs to M. Piet-Lataudrie, a well-known French collector, from whom Messrs. Stanley Gibbons \& Co. purchased the two Mauritius for the record price of $£ 680$, for an English collector. The Mauritius are not by any means the rarest stamps in the world, for there are some of which only one copy exists. A rarer stamp, for instance, is the 2 cents, rose, of the $185 \mathrm{I}$ 


\section{Postage Stamps}

issue of British Guiana, of which only six are known, and three of these are in a Paris collection and one in the British Museum. This stamp is quite the most clumsy one ever issued, resembling a careless post-mark more than anything else. The 1856 issues of the same place are also exceedingly rare, and some of the varieties are worth nearly $f \mathrm{I}$ oo, whilst an error of this issue, the I cent, on crimson paper, has been valued at more than $£ 250$. The first issue of the French Island of Réunion is rare from an adventitious circumstance: the stock was nearly entirely consumed by philatelic white ants within a few days of publication, and the market value of the pair, I 5 and 30 centimes, is about $£ \mathrm{roO}$. The earliest issues, 2,5 , and I 3 cents (all blue), of the Sandwich or Hawaiian Islands, I $85 \mathrm{I}$, are also practically unobtainable; if an example of the 2-cent issue came into the market it would realise probably not less than $£ 200$. In connection with these Hawaiian stamps, it may be mentioned that they were set from types with an ornamental border, the value occupying the centre, and there are two varieties of each value. They were struck off "from time to time as required, and printed on any kind of paper that happened to be in the market. The result was that there were a great number of slight variations in the I 40 


\section{Postage Stamps}

minutiæ of paper and shade of colour, which are all-important to the genuine philatelist." The Hawaiian Government has for a long time manufactured and reprinted stamps solely for collectors, "the result of which is that the postal surplus, which was nil before the reprinting era, now averages $£ 40,000$ per annum." Some of the ugliest stamps in the world, the first issue of Moldavia, fetch very high figures in the market. In 1873 the set of three was to be had for a mere trifle-they would now realise perhaps $£$ I5O; one example alone sold at auction three years ago for $£ 49$, and is now valued at $£ 70$. The ro centavos, green, of Bolivar, 1863 , likewise one of a trio, is now worth $£ 6$; twenty years ago this could have been had for 2s. 6d. Certain Cape of Good Hope stamps are much sought, and Philatelic Vendor invoices them accordingly. Several of these owe their popularity to the carelessness of the printer. In the I 86I issue of provisionals of the triangular stamps, a 4 d. block was accidentally inserted instead of the Id.; used it is now valued at about $£ 30$, unused it would probably sell for $£$ I 50 ; twenty years ago this stamp was to be had at $3 \mathrm{~s}$. The investment in this case might certainly be considered a good one. Another would be the I2d. black of Canada, I85 I, which sold in 1873 for Ios., and is now 


\section{Postage Stamps}

worth about a hundred times that amount if in fine condition.

Such are some of the top prices in philately. The guiding principle of this science is clearly neither beauty nor utility, but simply and solely rarity. When we are in touch with those greater spirits with whom the price has merely to be intimated to bring an immediate cheque, it seems waste of time and thought to advise the people (there are some in the world!) who are actually content to put up with reprints of the rarer stamps. We need not mention the estimation in which Philatelic Vendor holds such, for he, as we need scarcely say, despises reproductions, and does not quite know whether there are things of that kind.

Twenty years ago it was a most uncommon thing to come across a stamp priced at $£ \mathrm{I}$ or over in a dealer's catalogue; the majority of items, in fact, came well under Is. each. The Bahamas Id. stamp of 1859 and the $6 \mathrm{~d}$. one of I86I might have been had together in 1873 for $8 \mathrm{~d}$.; to-day they sell for close on a $£ 5$ note. The Ceylon blue Id. might have been had in 1873 at $9 \mathrm{~d}$. per dozen used; they are now worth Is. each; the $8 \mathrm{~d}$. chocolate (1857), once retailed at 3 s. the dozen, now sells by auction at five guineas each; but one of the greatest rarities in the Ceylon issues is the $8 \mathrm{~d}$. octagonal yellow-brown 


\section{Postage Stamps}

(I86I), of which unused examples have risen in twenty years from eighteenpence to over $£ \mathrm{I}$, whilst an American dealer prices an example at 30 dollars. In fact, all the Ceylon issues, I 857 to 1867 , have greatly increased in value.

Among the highest priced stamps in 1873 , Antioquia took the lead with its $2 \frac{1}{2}, 5$, and Io centavos, which were offered together at the then high figure of $£ 4$. In January I894, Messrs. Cheveley sold a very good set for $£ 36$, Ios. So, too, the 20 centimos of Fernando Po (I868), which was sold at I 5 s. unused in 1873 , has now doubled in value, the unused being worth only about Is. more than the used example, then priced at ros. The two French stamps, 10 centimes cinnamon, and 25 centimes blue, issued during the Presidency of Louis Napoleon in 1852 , were offered at $4 \mathrm{~s}$. $6 \mathrm{~d}$. and $2 \mathrm{~s}$. $6 \mathrm{~d}$. respectively in $\mathrm{I} 873$; now the former realises $\mathscr{E} \mathrm{I}$, and the latter about $6 \mathrm{~s}$.

As regards the stamps of this country, the Id. black, with the initials V.R. in the upper corner, maintains its position, both on the score of rarity and of price. Many collectors refuse to admit it into their collections, on the theory that it was never actually issued, and is, consequently, only an "essay" and not a legitimate stamp-a point, by the way, on which Mr. Booty has a good deal to say 


\section{Postage Stamps}

in his lithographic monograph. They also argue that the few used examples were simply appropriated by officials for their private letters, and escaped detection in going through the post. The best philatelic authorities, however, are of opinion that the V.R. is a genuine postage stamp; at all events, its I 873 value of $£ 2$ has now increased to five times that amount. This, as already stated, is almost our only valuable stamp, but the Mulready envelope has risen from 3s. 6d. to $£ \mathrm{I}$. The Is. stamp of 1847 , however, which, unused, sold at its facial value twenty years ago, is now worth nearly $£ 3$, whilst the $6 \mathrm{~d}$. violet of I 864 is now priced at about $£ \mathrm{r}$. In January I894 a "magnificent unused strip of three" examples of the 8d. brown, "with gum intact," realised $£ \mathrm{I} 6$; an unused block of six of the 2s. salmon realised $£$ I 8 at Messrs. Cheveley's auction -in each case an uncommonly good investment for the original purchasers. Buyers of unused English stamps at par value can always console themselves with the reflection that they are never likely to lose over the transaction, for the stamps of this country have never been demonetised.

India had in its 1854 or first issue two half-anna stamps, one of which, the blue, is common enough, and sells for a few pence, but the red variety is very rare, and realises 


\section{Postage Stamps}

from five to seven guineas under the hammer. Many of the early Newfoundland stamps also fetch high prices in the auction-room, particularly the Is. issue of 1857 , which is sometimes found orange-vermilion, and at others carmine-vermilion in colour, the prices ranging from $£ 5$, Ios. to $£ 7$, Ios. according to condition, " a tiny tear at left side" in one instance making a difference of $£ \mathrm{I}, \mathrm{I} 5 \mathrm{~s}$. in the value! Even in 1873 these stamps were rare, the then high amount of $\mathrm{I} 8 \mathrm{~s}$. each being asked. Few Peruvian stamps realise fancy prices, the chief exceptions being the medio peso, rose, of I 858 , very fine examples of which now realise from $£$ I I to $£$ I 2 each. Another South American Republic, Buenos Ayres, included among its first issues a few stamps which have since become very rare, notably the 5 pesos, orange, I 858 , a used example of which was valued at $£ 2$, Ios. as far back as 1873 , but which is now worth about twelve guineas; the 4 pesos, red, of the same issue has only advanced from $£ 3$ to from six to nine guineas (Philatelic Vendor scarcely deems it worth while to draw your attention to it in the bill), and the 3 pesos, green, has advanced from I 5 s. to $\delta 3$, more or less, in a similar period.

If the United States stamps are not as a rule beautiful, they are, at all events, very numerous, and that, perhaps, is sufficient for

$$
\text { I } 45
$$




\section{Postage Stamps}

the average American. A complete collection of the United States issues would involve the expenditure of much time and money. To begin with, the provisional issue of the 5 cents Brattleboro', I 846, would cost at least $£ \mathrm{IOO}$, and might be perhaps all but impossible to obtain even at that price. Another rare example, viz., the 5 cents blue stamp issued by the Alabama Government at Livingston during the war, recently sold at auction in New York for 780 dollars. The stamps issued by the Confederate States are now of the greatest rarity; recently one of these (? 2 cents green), of Baton Rouge, Louisiana, "went for 99 dollars to a man who said his name was Philip," as the New York reporter put it; another, the 5 cents of the same place, realising 98 dollars. The St. Louis 5, IO and 20 cents stamps are also among the rarest of the local issues. In I 872 the 5 cents realised just over I $7 \mathrm{~s}$. each, and the IO cents about I2s.; fine examples of these now realise from six guineas to $£ 8$, Ios. respectively, while the value of the 20 cents stamp is somewhere in the neighbourhood of $£$ i००. There is, besides the regular official issues, an enormous series of local and provincial stamps, and the endless Pony Expresses and curious postal media employed by trading firms in years gone by. Some of these are extremely I 46 


\section{Postage Stamps}

characteristic and picturesque, and their scarcity is apt to grow.

A few examples of the United States I 5 cents and 24 cents 1869 issues, with inverted centres, got into circulation, and are now appraised at $£ \mathrm{I} 7$ and $£ \mathrm{I} 8$, IOs. respectively, the values of the correct impressions being less than half as many shillings. In the Mauritius I 848 2d. blue, one variety reads "penoe" instead of "pence:" the example with the error is valued at $\mathscr{E}$ IO, but for the one without it Philatelic Vendor accepts a complimentary douceur of five guineas. But the most famous of all "errors" in this direction is the "Connell" stamp of New Brunswick, in which the then postmaster, thinking that his own portrait would be as acceptable to the natives as that of his sovereign, had 5 cent stamps so ornamented in $186 \%$. Not many, however, got into circulation. In 1873 it was selling at $7 \mathrm{~s} .6 \mathrm{~d}$. each unused; a good specimen now sells readily at $£ 20$. Think of that, Master Brook!

Philately has often been the arena of "bulls" and "bears;" and in dealing in stamps it is as necessary for one to be wide awake as in other forms of speculation. An attempt at " a corner" is said to have been made in regard to the United States Columbian issue, but it was unsuccessful. A similar 


\section{Postage Stamps}

move was made when the United States Government was about to cease the issue of ro cent stamped envelopes. A certain dealer bought I0,000 examples, for which he paid I000 dollars, and was sufficiently "previous" to issue a circular to the effect that collectors would be able to buy examples after a certain date at a fancy figure. The Postal Department was inundated with protests from those who had not taken time by the forelock. The virtuous officials (being outside) resented the trick; the decision to suspend the issue was revoked, and I 50,000 more were printed off. A certain Don Juan Cardillas, MonteVideo, collected over I00,000 examples of the Uruguay 5 cent blue of I 883, with the figure of General Santos. But a very large number of this issue had been struck off, and the unfortunate speculator would not have realised a profit on his transaction until he had reached the age of Methuselah; so, not content to wait, and finding it impossible to make this stamp rare by fair or other means, Don Cardillas set fire to the lot.

But the day of the great prizes is gone; only very few people recognised the extent to which the hobby would develop itself. They held on in the anticipation of a rise, and the rise came. It is now too late for others to enter into the fray in the expecI 48 


\section{Postage Stamps}

tation of making a good thing out of it. Stamps are either very rare or very common - very expensive or very cheap. The rarities to which allusion has been made constitute an insignificant minority, which there is not a very good prospect of swelling from new sources. At the same time, the peculiarly unsatisfactory features and conditions of stampcollecting, which afford exceptional facilities for deception, and reduce the test of genuineness, for the most part, to the water-mark of the paper on which the stamp has been printed, must in due course deter many from prosecuting the taste, since the fad has passed from the hands of the young into those of their seniors, who may now and then grow weary at last of working early and late to find the tribute-money for that most insatiable, albeit most veracious and upright, of modern commercial celebrities, Philatelic Vendor, previously quoted. 

Index 



\section{Index}

AlDus, first book printed by, I6

Americana, 26

American stamps, 145

Antioquian stamps, 143

Apponyi Library, the, IO-II

Arbuthnot, Mr. E. O., I I 3

Auction, the first stamp, $13^{6}$

BALBI Catholicon, the, I3

Beckford Library, 7, 8, 9

Berghem, N., 62

Bernal sale, Iog

Bible, the English, 13-14

Blue and white porcelain, III, I I2, II 3

Bohn collection of porcelain, I09

Booty, Frederick, 129

Both, Jan, 6r

Botticelli, 74

Bow ware, 126

Brinkley, Captain, II 3

Bristol ware, 125

British Guiana stamps, I40

British School of Painting, 7980

British stamps, I43
Browning, Robert, 39, 40-4I

Buen Retiro china, I 22

Burghley House china, II I

Byron, Lord, 37-38

CAfFagiolo ware, 122

Callcott, Sir A. W., 90, 9I

Canaletto, 74

Capo di Monte ware, 122

Cassiobury Park sale, II7

Caxton, works printed by, 19-22

Ceylon stamps, 142

Chelsea ware, I 24

China, Charles Lamb on, 105

China collecting, ro5 et seq.

Cole, Vicat, $8 \mathrm{I}$

Constable, John, 80

Cooper, Mr. T. S., 98

Correggio, 75

Coventry vases, the, II 5-116

Cox, David, 86-87

Crivelli, Carlo, 76

Cuyp, a, 6I

Defoz's "Robinson Crusoe," 25

Derby ware, 126 


\section{Index}

De Wint, Peter, 87

Dickens, first editions of, 29, 32

Dickins' collection of china, I 10

Dolci, Carlo, 76

Dow, Gerard, 73

Dresden china, I 19

Dudley's (Lord) collection of Sèvres, 116

Dutch School of Painters, 60

Eastlake, Sir Charles, 90

Editiones principes, II

Egremont, Earl of, 73

Etty, W., 90

FAED, T., 98

Ferrary, Herr Philip von, I34

Fielding, Copley, 87

First editions, the cult of, 28

French stamps, 143

Frith, Mr. W. P., 98

GaInsBorough, Thomas, 85

Giorgione, 77

Gladstone, Mr., I09, 122

Goldsmith's " Vicar of Wakefield," 25

Goodall, Mr. F., 96

Grant, Sir F., 99

Gray, Dr. J. E., 136

Gray's "Elegy," 25

Greek, first book printed in, 15-16

Grolier's copy of Lucretius, 18 Gubbio pottery, 120
Hamilton Palace sale, 70, i I 8

Hardy, Mr. Thomas, 45, 46

Hawaiian stamps, I4I

Heber, Richard, 4

Henri Deux ware, I22

Hertford, Lord, I 18

Hispano-Moresque ware, I2I

Hobbema, M., 64, 65

Hodgson sale, 118

Homer, editio princeps, I5

Hooch, P. de, 63

Hook, Mr. J. C., 98

Hope, Adrian, 60

"Hypnerotomachia Poliphili,"

17

JEFFERIES, R., 42, 44

Jones, Sir E. Burne, 97

Joseph, the late E., 12 I

KEENE'S "Memoirs of his Life," 25

LAMB, Charles, 35, 105

Landseer, Sir E., 9I-93

Lang, Mr. Andrew, 42, 43

Leighton, Sir F., 99

Lewis, C. J., 8I

Lewis, J. F., 88

Limited editions, 49

Lippi, F., 77

Lonsdale china, I Io

MAURITIUS stamps, I 39

Mazarin Bible, the, 12, 13 


\section{Index}

Memlinc, Hans, 63

Meredith, Mr. George, 45

Millais, Sir J., 97

Milton, John, 24

Moldavian stamps, 14I

Motives for collecting books, 6

Müller, W. J., 89

Murietta, Messrs., 82

NASMYTh, Peter, 94

Neglected books, 4-5

Newfoundland stamps, 145

Ostade, A. and I., 65-66

Ovid, editio princeps, 16

"Paradise Lost," 6-7

"Pastissier François," Le, I

Pedigrees of pictures, 59

Perkins sale, the, 12

Philatelic Society, the, I33

Picture dealers, 53

Pictures, 53-I0I

Poole, P. F., 94

Postage stamps, 129-149

Pottery and porcelain, 105-126

Price, David, 57

Psalmorum Codex, the, 13

RAPHAEL, 77

Rare books and their prices,

$$
\text { I-50 }
$$

Rembrandt, 66-67
Reynolds, Sir Joshua, 83, 84

Roberts, David, 93

Romney, George, 83

Rosa, Salvator, 79

Rossetti, D. G., 95

Rubens, P. P., 70

Ruskin, John, 4I-42

Ruysdael, 68

SARTo, Andrea del, 79

Scott, Sir Walter, 38

Sèvres porcelain, II5

Shakespeare, works of, 22-23

Shelley, P. B., 36-37

Shuldham, Dr. E. B., II 3

Sloane, Sir Hans, I 24

Spenser, E., 24

Spitzer sale, the, I2I

Stamp collecting, its origin, 131, I32

Stamp collections, some, 134

Stanfield, Clarkson, 9I

Stephen, J. K., 49

Stevenson, R. L., 47

Summer Palace, Pekin, II 4

Sunderland Library, 7, 8, II

Syston Park Library, 9

TADema, Mr. Alma, 97, 98

Tapling, T., I35

Teniers, D., $7 \mathrm{I}$

Tennyson, Lord, 39, 40

Thackeray, first editions of,

29, 32, 33

Tintoretto, 79 


\section{Index}

Turner, J. M. W., 93-94

Tyndall, Professor, 46

URBINo pottery, 120

VALDARFER Boccaccio, the, 14-15

Van de Veldes, A., 72

Virgil, editio princeps, 15
WALPOLE, Horace, I05

Walton's "Angler," 24

Warton's " History of English

Poetry," 3

Webster, T., 9r

Wilkie, Sir David, 93

Worcester ware, 126

Wouverman, 72

Wynant, J., 72

THE END

Printed by Ballantyne, Hanson \& Co.

Edinburgh and London 


\section{HART STREET}

BLOOMSBURY LONDON

November 1895 .

\section{The}

\section{Collector Series$$
++
$$

$M^{\text {R. GEORGE REDWAY begs to }}$ VI announce the publication of this series of books, each volume of which will discuss some one of the subjects which are of interest to Collectors.

Coins and Medals, Engravings, Pictures and Drawings, Postage Stamps, Book Plates, Autographs, Armour and Weapons, Plate, Porcelain and Pottery, Old Violins, Japanese Curios, and Bric-à-brac of all sorts will be dealt with, each in a separate volume, and by a writer specially conversant with his subject. The instinct for collecting has been made the butt for much 
cheap ridicule by those who confound it with the mere aimless bringing together of objects which have no other merit than their rarity. But it has repeatedly been proved that skill and patience are more helpful to success in collecting than length of purse, and it is especially for those who desire to pursue their amusement with intelligent economy that this series has been planned.

The great prizes in the older forms of collecting have long since been won, and though it may be needful in these handbooks to refer occasionally to a book, a coin, a postage stamp, or a particular "state" of an etching or engraving, of which only a single example exists, the object of the series will mainly be to describe those specimens which are still attainable by the amateurs who will take the pains to hunt then down.

For this reason, though the series will be written by experts, it will be written by experts who have in view, not the visitors to the great Museums of Europe, but the amateur and collector of moderate means, who is anxious to specialise in some one or two departments of his favourite studies, and to whom it is still 
open by care and judgment to bring together, at a moderate expense, small yet perfect collections which any museum would be glad to possess.

Arrangements have been made with many well-known writers and specialists for their assistance as authors or editors of volumes of the series.

Each volume will contain from 250 to 300 octavo pages, from twelve to twenty plates, and a title-page designed by Mr. Laurence Housman. The series will be printed, from new type, on specially-prepared paper, by Messrs. Ballantyne, Hanson \& Co.

Volumes on Coins, Miniatures, Prints, Postage Stamps, Book Plates, Old Bibles, Drawings, Glass, Old Violins, \&c., are now in hand, and publication will be commenced on the Ist of December.

The price of each volume of the series will be $6 s$. or 7 s. $6 d$. net.

The Publisher reserves the right to issue a 
limited number of copies of any volume of the series either on Japanese vellum or Whatman or India paper, or with the illustrations in "proof" state, according as the subject of the book may suggest. The number and price of these will be announced in each case, and they will be strictly reserved for Subscribers before publication.

The Series will be published in America by Messrs. Longmans, Green \& $\mathrm{Co}$. 





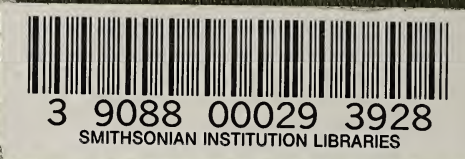

